\title{
MicroRNAs in Differentiation of Embryoid Bodies and the Teratoma Subtype of Testicular Cancer
}

\author{
METTE PERNILLE MYKLEBUST ${ }^{1}$, ANNE METTE SØVIKNES ${ }^{2}$, OLE JOHAN HALVORSEN ${ }^{3}$, \\ ANNA THOR ${ }^{4}$, OLAV DAHL $^{1,5}$ and HELGE RÆDER ${ }^{2,6}$ \\ ${ }^{1}$ Department of Oncology and Medical Physics, Haukeland University Hospital, Bergen, Norway; \\ ${ }^{2}$ Center for Diabetes Research, Department of Clinical Science, University of Bergen, Bergen, Norway; \\ ${ }^{3}$ Gade Laboratory for Pathology, Department of Clinical Medicine, \\ Centre for Cancer Biomarkers CCBIO, University of Bergen, Bergen, Norway; \\ ${ }^{4}$ Department of Urology and CLINTEC Karolinska Institutet, Karolinska University Hospital, Stockholm, Sweden; \\ ${ }^{5}$ Department of Clinical Science, Faculty of Medicine, University of Bergen, Bergen, Norway; \\ ${ }^{6}$ Department of Pediatrics, Haukeland University Hospital, Bergen, Norway
}

\begin{abstract}
Background: Testicular germ cell tumours (TGCTs) are the most frequent tumour type among young, adult men. TGCTs can be efficiently treated, but metastases of the teratoma subtype, for which there are no circulating biomarkers, represent a challenge. Materials and Methods: Global microRNA expression in teratoma tissue and embryoid bodies was assessed using next-generation sequencing. Levels of microRNAs identified as potential biomarkers were obtained from serum of patients with teratoma and matched healthy men. Results: We identified miR-222-5p, miR-200a-5p, miR-196b-3p and miR-454-5p as biomarker candidates from the tumour tissue and embryoid body screening but the expression of these microRNAs was very low in serum and not statistically different between patients and controls. miR-375-3p was highly expressed, being highest in patients with teratoma $(p=0.012)$ but the levels of expression in serum from these patients and healthy controls overlapped. miR-371a-3p was not expressed in serum from patients with pure teratoma, only in patients with mixed tumours. Conclusion: The microRNA profiles of the teratoma subtype of TGCT and embryoid bodies were obtained and assessed for candidate circulating biomarkers, but none with high sensitivity and specificity for teratoma were identified in our study. We conclude that neither the proposed teratoma
\end{abstract}

This article is freely accessible online.

Correspondence to: Mette P. Myklebust, Haukeland University Hospital, Department of Oncology and Medical Physics, Mohn Cancer Research Laboratory, Jonas Lies vei 91B, 5021 Bergen, Norway. E-mail: mette.pernille.myklebust@helse-bergen.no

Key Words: MicroRNAs, testicular cancer, teratoma, biomarker, embryoid bodies, miR-371a-3p, miR-375-3p. marker miR-375-3p nor miR-371a-3p are suitable as circulating teratoma markers.

Testicular germ cell tumours (TGCT) are rare and account for less than $1 \%$ of all male cancer but represent the most common malignancy among young men between 15-40 years (1). The incidence of TGCT has been rising and is highest in men of northern European ancestry (2). Known main risk factors for TGCT are cryptorchism, prior diagnosis, increased adult height and a familial history of TGCT $(3,4)$. Gain of chromosome $12 \mathrm{p}$ and aneuploidy are found in nearly all cases (5) and more than 40 susceptibility loci with moderate risk have been identified $(6,7)$. These include KIT and KRAS, but with no major high-risk genes (8-10). Although genetic risk factors are observed, the rapid increase in TGCT incidence seen in Western countries since the 1950s cannot be explained by genetic factors alone. A gene-environmental model has been proposed where genetic factors work in concert with environmental and lifestyle factors (11). The associations of TGCT with environmental/lifestyle factors are debated and are generally considered weak, but include, among others, dietary intake, physical exercise, birth weight, exposure to hormones in utero, maternal smoking, parity and reduced gestational age (12).

The majority of TGCTs are thought to arise from intratubular, incompletely differentiated embryonal cells where a failure in control of their latent developmental potential and reprogramming gives raise to germ cell neoplasia in situ (13, 14). According to the World Health Organization's 2016 classification of testicular germ cell tumours, germ cell neoplasia in situ-derived tumours are further classified into seminomas, embryonal carcinoma (EC), yolk sac tumour, trophoblastic tumours (e.g., choriocarcinoma) and post-pubertal teratoma (15). Seminomas and EC are both undifferentiated, 
Table I. Samples included in the tissue screen for microRNA in teratomas.

\begin{tabular}{|c|c|c|c|c|}
\hline Patient & Primary diagnosis & Sample & Tissue extracted at & Tissue extracted* \\
\hline \multirow[t]{2}{*}{ ID1 } & \multirow[t]{2}{*}{$100 \%$ Teratoma, extragonadal CS4 } & 1-1 Mediastinum & Surgery after $\mathrm{CHT}$ & Teratoma \\
\hline & & 1-2 Lung & Surgery after CHT & Teratoma \\
\hline \multirow[t]{4}{*}{ ID2 } & \multirow[t]{4}{*}{$99 \%$ Teratoma $+1 \%$ Sem, CS2 } & 2-1 Testis & Orch prior to $\mathrm{CHT}$ & Teratoma \\
\hline & & 2-2 Testis & Orch prior to $\mathrm{CHT}$ & Normal testis \\
\hline & & 2-3 Lymph node, RPLND & pcRPLND & Teratoma \\
\hline & & 2-4 Lymph node, RPLND & pcRPLND & Teratoma \\
\hline \multirow[t]{2}{*}{ ID3 } & \multirow[t]{2}{*}{$50 \%$ Teratoma $+50 \%$ EC, CS 1} & 3-1 Testis & Orch prior to $\mathrm{CHT}$ & Teratoma \\
\hline & & 3-2 Testis & Orch prior to $\mathrm{CHT}$ & Normal testis \\
\hline \multirow[t]{4}{*}{ ID4 } & \multirow[t]{4}{*}{$20 \%$ Teratoma $+79 \%$ EC, $1 \%$ YST, CS2 } & 4-1 Testis & Orch prior to $\mathrm{CHT}$ & Normal testis \\
\hline & & 4-2 Lymph node, RPLND & pcRPLND & Teratoma \\
\hline & & 4-3 Lymph node, RPLND & pcRPLND & Teratoma \\
\hline & & 4-4 Lymph node, RPLND & pcRPLND & Normal lymph node \\
\hline \multirow[t]{3}{*}{ ID5 } & \multirow[t]{3}{*}{$20 \%$ Teratoma $+70 \%$ Sem, $10 \%$ EC, CS 1} & 5-1 Testis & Orch prior to $\mathrm{CHT}$ & Teratoma \\
\hline & & 5-2 Testis & Orch prior to $\mathrm{CHT}$ & Teratoma \\
\hline & & 5-3 Testis & Orch prior to $\mathrm{CHT}$ & Normal testis \\
\hline ID6 & $50 \%+$ Teratoma $40 \% \mathrm{EC}+5 \% \mathrm{YST}+5 \% \mathrm{Sem}, \mathrm{CS} 1$ & 6-1 Testis & Orch prior to $\mathrm{CHT}$ & Teratoma \\
\hline \multirow[t]{3}{*}{ ID7 } & $65 \%$ Teratoma, $25 \%$ EC & 7-1 Lymph node, RPLND & pcRPLND & Normal lymph node \\
\hline & $8 \%$ Sem and $2 \%$ Chorio, CS2 & 7-2 Lymph node, RPLND & pcRPLND & Teratoma \\
\hline & & 7-3 Lymph node, RPLND & pcRPLND & Teratoma \\
\hline
\end{tabular}

CHT: Chemotherapy; CS: clinical stage; Chorio: choriocarcinoma; EC: embryonal carcinoma; Orch: orchiectomy; pcRPLND: post-chemotherapy retroperitoneal lymph node dissection; Sem: seminoma; YST: yolk sac tumour. When two or more samples were extracted from the same sample location, they were spatially separated. *All tissue samples were carefully extracted from areas with pure teratoma or normal tissue.

where EC is pluripotent and the origin of the diverse group of non-seminomas. In oncological treatment, a distinction is made between seminoma and non-seminoma histological types, with seminomas being characterised by higher mean age at diagnosis and better prognosis. All mixed tumours are defined as non-seminomas due to their more aggressive nature and poorer prognosis. The teratoma subtype is the most highly differentiated type of the non-seminomas. In contrast to the prepubertal-type, the postpubertal-type teratomas grow invasively and can metastasise (16-19). The histology of teratomas may show elements of all three germ layers, with the originating germ cell layer differentiated into somatic tissue (20). The presence of a mature teratoma component in the primary tumour has been associated with both early and late mortality from TGCT $(21,22)$. Furthermore, one study found a high frequency of yolk sac tumours in late relapses and hypothesised that the yolk sac tumours may have developed from residual teratoma (23). Recently, it was shown through genetic analyses of teratomas and adjacent somatic transformed tumour cells that it is more likely that progenitor cells in teratomas differentiate into diverse cellular lineages rather than progeny cells dedifferentiating into stem-like cells through genetic mutations (24).

Teratomas with their features of highly differentiated somatic tissue have been linked to cisplatin resistance (2528). Slightly enlarged lymph nodes that do not shrink as expected following chemotherapy represent a challenge in the management of TGCT and surgical removal is the only available treatment (29). The question is usually whether the mass visible at images represents teratoma, viable tumour or non-viable deposits. The classical markers in TGCT, namely human choriogonadotropin type beta $\left(\mathrm{hCG}_{\beta}\right)$ and alphafetoprotein (AFP) are not expressed by teratomas. The teratomas are not reactive in fluorodeoxyglucose positronemission tomography (30). Circulating miR-371a-3p has been shown to be highly sensitive in detecting TGCT cells except for the teratoma sub-type (31). No biomarker for teratoma has been identified so far. miR-375-3p has been proposed as a teratoma marker $(32,33)$ but the clinical utility of this microRNA as a circulating biomarker is debated (3436). Thus, research for new circulating markers for teratoma is highly warranted.

Grown in suspension culture, human embryonic stem cells (hESCs) and human induced pluripotent stem cell (hiPSCs) both have the ability to spontaneously form three-dimensional aggregates of differentiated embryoid bodies (EBs) comprising all the three embryonic germ layers (37). EBs thus serve as a model of human embryos to study early differentiation events (38). In fact, the first experiment to demonstrate the pluripotency of embryonal carcinoma cells showed that single cells from EBs were able to generate tumours containing embryonal carcinoma cells and somatic tissues in a murine model (39). Individual EC cells were shown to be able to differentiate into well-differentiated, adult-appearing somatic tissue, representing all three germ layers. Today, the formation of spontaneously or (chemically) 
Table II. Characteristics of patients included in the serum microRNA analyses.

\begin{tabular}{|c|c|c|c|c|c|c|c|}
\hline Patient & $\begin{array}{l}\text { Primary } \\
\text { diagnosis }\end{array}$ & Stage & $\begin{array}{l}\text { Histological } \\
\text { diagnosis at time of } \\
\text { serum sample }\end{array}$ & $\begin{array}{l}\text { Sample } \\
\text { timepoint }\end{array}$ & $\begin{array}{l}\text { FFPE } \\
\text { screen }\end{array}$ & $\begin{array}{l}\text { Serum } \\
\text { RT-qPCR } \\
\text { screen }\end{array}$ & $\begin{array}{c}\text { Serum } \\
\text { RT-qPCR } \\
\text { panel }\end{array}$ \\
\hline ID1 & $100 \%$ Teratoma, mediastinum & CS4 & - & Pre-treatment & $\mathrm{x}$ & $\mathrm{x}$ & $\mathrm{x}$ \\
\hline ID2 & $99 \%$ Teratoma, $1 \%$ Sem & $\mathrm{CS} 2$ & - & Pre-orch & $\mathrm{x}$ & $\mathrm{x}$ & $\mathrm{x}$ \\
\hline ID3 & $50 \%$ Teratoma, $50 \%$ EC, necrosis & CS1 & - & Pre-orch & $\mathrm{x}$ & $\mathrm{x}$ & $\mathrm{x}$ \\
\hline ID4 & Teratoma, EC and YST & $\mathrm{CS} 2$ & $100 \%$ Teratoma & Pre-RPLND & $\mathrm{x}$ & $\mathrm{x}$ & $\mathrm{x}$ \\
\hline ID5 & $60 \%$ Teratoma, $40 \%$ Sem & $\mathrm{CS} 2$ & $100 \%$ Teratoma & Pre-RPLND & $\mathrm{x}$ & $\mathrm{x}$ & $\mathrm{x}$ \\
\hline ID6 & $50 \%$ Teratoma, $40 \%$ EC, $5 \%$ YST, $5 \%$ Sem & $\mathrm{CS} 1$ & - & Pre-orch & $\mathrm{x}$ & - & - \\
\hline ID7 & $65 \%$ Teratoma, $25 \%$ EC, $8 \%$ Sem, $2 \%$ Chorio & $\mathrm{CS} 2$ & $100 \%$ Teratoma & Pre-RPLND & $\mathrm{x}$ & - & - \\
\hline ID8 & $50 \%$ Teratoma, $50 \%$ YST & $\mathrm{CS} 2$ & - & Pre-orch & - & $\mathrm{x}$ & $\mathrm{x}$ \\
\hline ID9 & $55 \%$ Teratoma, $45 \%$ YST & $\mathrm{CS} 1$ & - & Pre-orch & - & $\mathrm{x}$ & $\mathrm{x}$ \\
\hline ID10 & $100 \%$ Teratoma & $\mathrm{CS} 2$ & - & Pre-orch & - & $\mathrm{x}$ & $\mathrm{x}$ \\
\hline ID11 & $100 \%$ Teratoma & $\mathrm{CS} 1$ & - & Pre-orch & - & $\mathrm{x}$ & $\mathrm{x}$ \\
\hline ID12 & $80 \%$ Teratoma, $20 \%$ EC & $\mathrm{CS} 1$ & - & Pre-orch & - & $\mathrm{x}$ & $\mathrm{x}$ \\
\hline ID13 & EC, focal YST & $\mathrm{CS} 3$ & $100 \%$ Teratoma & Pre-RPLND & - & $\mathrm{x}$ & $\mathrm{x}$ \\
\hline ID14 & $80 \%$ EC, $15 \%$ teratoma, $5 \%$ chorio & $\mathrm{CS} 2$ & $100 \%$ Teratoma & Pre-RPLND & - & $\mathrm{x}$ & $\mathrm{x}$ \\
\hline ID15 & Sem, EC, YST and teratoma & $\mathrm{CS} 2$ & $100 \%$ Teratoma & Pre-RPLND & - & $\mathrm{x}$ & $\mathrm{x}$ \\
\hline ID16 & $\mathrm{EC}+\mathrm{GCNIS}$ & $\mathrm{CS} 2$ & $100 \%$ Teratoma & Pre-RPLND & - & $\mathrm{x}$ & $\mathrm{x}$ \\
\hline ID17 & $100 \%$ Teratoma & $\mathrm{CS} 2$ & $100 \%$ Teratoma & Pre-RPLND & - & - & $\mathrm{x}$ \\
\hline ID18 & $100 \%$ Teratoma, extragonadal & $\mathrm{CS} 4$ & $100 \%$ Teratoma & Pre-RPLND & - & - & $\mathrm{x}$ \\
\hline
\end{tabular}

Chorio: Choriocarcinoma; CS: clinical stage; EC: embryonal carcinoma; FFPE: formalin-fixed paraffin-embedded tissue; GCNIS: germ cell neoplasia in situ; Pre-orch; sample drawn before orchiectomy or start of treatment; Pre-RPLND; sample drawn <48 h prior to RPLND; Pre-treatment; sample drawn prior to start of any treatment; RPLND: retroperitoneal lymph node dissection; RT-qPCR: reverse transcriptase-quantitative polymerase chain reaction; Sem: seminoma; YST: yolk sac tumour. Patients ID6 and ID7 did not have serum samples available for the timepoints in question.

induced EBs in suspension culture is used to demonstrate pluripotency of stem cells [reviewed in (40)], as an alternative to testing teratoma formation capability after injection into the neck of mice.

In the present study, we aimed to identify one or several microRNAs as potential novel, clinical biomarkers for teratoma using EBs as a model, due to the histological similarity between teratomas and EBs and the possibility to study EBs in a time-course manner including early phases during their development from pluripotent stem cells. Specifically, we aimed to correlate microRNA expression in evolving EBs to their expression in teratoma tissue and sera from patients with teratoma in order to identify novel disease-specific microRNA markers.

\section{Materials and Methods}

Formation of EBs. In addition to the hESC line H1, pluripotent stem cells were obtained from fibroblasts from two healthy control donors (named N26 and N904), and reprogramming of fibroblasts into induced pluripotent stem cells was performed, as previously described (41), by episomal reprogramming. EBs were aggregated from stem cells by following the instruction of the AggreWell ${ }^{\mathrm{TM}} 800$ starter kit (Stem Cell Technologies, Vancouver, Canada). Cells were harvested with gentle dissociation reagent (Stem Cell Technologies) and resuspended in EB formation medium (Stem Cell Technologies) with $10 \mu \mathrm{M}$ Y-27632. In each well, 1.2 million cells were plated and incubated for $24 \mathrm{~h}$ in a cell incubator. The EBs were harvested and spontaneous differentiation was induced by culturing the EBs in primate ES cell media (Tebu bio, Le Perray-en-Yvelines, France) first 10 days in suspension plates (Sarstedt, Nümbrecht, Germany) followed by 30 days on plates (Sarstedt) coated with Matrigel (Fisher Scientific, Corning, NY, USA). Sampling was performed at days $0,8,20$ and 30 of the spontaneous differentiation.

Upon harvesting, the EBs were disrupted and homogenized in $600 \mu \mathrm{l}$ Buffer RLT Plus (Qiagen, Venlo, the Netherlands) and homogenized using a TissueLyzer LT (Qiagen) at $30 \mathrm{~Hz}$ for $2 \mathrm{~min}$ before exaction of total RNA using the AllPrep DNA/RNA/miRNA Universal Kit (Qiagen) according to the manufacturer's instructions. An on-column DNase-treatment step was included in the protocol. RNA was eluted in $30 \mu \mathrm{l}$ nuclease-free water.

Tissue and serum samples. Patients with at least 50\% teratoma in the primary tumour or metastases were identified among patients included in the SWENOTECA MIR study (ClinicalTrials.gov Identifier: NCT04914026). Archival paraffin tissue was retrieved from the Department of Pathology, Haukeland University Hospital (Table I), while blood samples were drawn in the SWENOTECA MIR study (Table II), before orchiectomy or before post chemotherapy retroperitoneal lymph node dissection (pcRPLND).

As a control group for serum analyses, we used serum from 30 healthy, age-matched male blood donors (42). We also downloaded datasets with global circulating microRNA expression data from healthy individuals in order to filter out microRNAs that are expected to be highly expressed in serum from healthy individuals $(43,44)$. 
Table III. List of miRCURY LNA miRNA polymerase chain reaction assays used for screening of serum samples.

\begin{tabular}{|c|c|}
\hline Target RNA & GeneGlobe Cat. No. \\
\hline hsa-miR-196b-3p & YP00206018 \\
\hline hsa-miR-455-3p & YP00204035 \\
\hline hsa-miR-181a-2-3p & YP00204142 \\
\hline hsa-miR-301b-3p & YP00204390 \\
\hline hsa-miR-1226-3p & YP02102736 \\
\hline hsa-miR-205-5p & YP00204487 \\
\hline hsa-miR-205-3p & YP00205602 \\
\hline hsa-miR-490-5p & YP00206077 \\
\hline hsa-miR-490-3p & YP00205999 \\
\hline hsa-miR-133b & YP00206058 \\
\hline hsa-miR-221-5p & YP00204032 \\
\hline hsa-miR-452-5p & YP00204301 \\
\hline hsa-miR-224-5p & YP00204641 \\
\hline hsa-miR-320d & YP00205667 \\
\hline hsa-miR-200c-5p & YP02119294 \\
\hline hsa-miR-429 & YP00205901 \\
\hline hsa-miR-141-5p & YP00206088 \\
\hline hsa-miR-934 & YP02119292 \\
\hline hsa-miR-223-5p & YP00204529 \\
\hline hsa-miR-27a-5p & YP00206021 \\
\hline hsa-miR-148a-3p & YP00205867 \\
\hline hsa-miR-326 & YP00204512 \\
\hline hsa-miR-301a-3p & YP00205601 \\
\hline hsa-miR-492 & YP00204053 \\
\hline hsa-miR-421 & YP00204603 \\
\hline hsa-miR-520a-3p & YP00204074 \\
\hline hsa-miR-26b-3p & YP00204117 \\
\hline hsa-miR-193a-5p & YP00204665 \\
\hline hsa-miR-6510-3p & YP02105880 \\
\hline hsa-miR-196a-5p & YP00204386 \\
\hline hsa-miR-365b-5p & YP00204654 \\
\hline hsa-miR-222-5p & YP00204314 \\
\hline hsa-miR-200a-5p & YP00206063 \\
\hline hsa-miR-200b-5p & YP00204144 \\
\hline hsa-miR-130b-3p & YP00204317 \\
\hline hsa-miR-133b & YP00206058 \\
\hline hsa-miR-181d-5p & YP00204789 \\
\hline hsa-miR-203a-3p & YP00205914 \\
\hline hsa-miR-21-3p & YP00204302 \\
\hline hsa-miR-425-5p & YP00204337 \\
\hline hsa-miR-23a-3p & YP00204772 \\
\hline hsa-miR-451a & YP02119305 \\
\hline hsa-miR-191-5p & YP00204306 \\
\hline hsa-miR-30b-5p & YP00204765 \\
\hline
\end{tabular}

RNA extraction from formalin-fixed paraffin-embedded (FFPE) tissue. Tumour areas containing pure teratoma were identified by an experienced uropathologist $(\mathrm{OJH})$. Two to four $1.0 \mathrm{~mm}$ diameter tissue cores were extracted from the paraffin blocks guided by encircled teratoma areas from corresponding hematoxylin and eosinstained slides. The FFPE tissue cores were disrupted in $600 \mu \mathrm{l}$ Deparaffinization Solution using Tissue Ruptor with disposable probes (all from Qiagen). RNA was further extracted according to the manufacturer's protocol for purification of total RNA including small
RNAs using an AllPrep DNA/RNA FFPE kit (Qiagen), on-column DNase treatment was performed, and RNA was eluted in $30 \mu \mathrm{l}$ nuclease-free water.

Blood sampling and RNA extraction from serum. Blood was collected by standard venipuncture technique into $10-\mathrm{ml}$ Vacutainer tubes with clot activator (BD, Franklin Lakes, NJ, USA). The samples were allowed to clot for $1 \mathrm{~h}$ prior to centrifugation at $2,000 \times g$ for $10 \mathrm{~min}$. Serum was carefully removed, aliquoted and frozen immediately at $-80^{\circ} \mathrm{C}$.

Prior to RNA extraction, serum was thawed, and haemolysis was assessed spectrophotometrically at $414 \mathrm{~nm}$ for all serum samples (45). Total RNA including small RNAs was extracted from $200 \mu \mathrm{l}$ serum using miRNEasy (Qiagen) and the supplementary protocol RY43 (Version Feb-11). Briefly, five volumes of Qiazol Lysis Reagent were added and vortexed for homogenization. Prior to addition of 1 volume of chloroform and centrifugation, $3 \mu \mathrm{g}$ glycogen (Thermo Fisher Scientific, Waltham, MA, USA) were added as carrier. The upper phase was carefully transferred to a new tube where 1.5 volumes of $96 \%$ ethanol was added, and column purification performed. RNA was eluted in $30 \mu \mathrm{l}$ nuclease-free water.

miRNA profiling by next-generation sequencing, from FFPE tissue and EBs. The RNA samples were submitted to Qiagen's nextgeneration sequencing service for microRNA profiling. Briefly, libraries were prepared using a QIAseq miRNA Library Prep kit (Qiagen) from $100 \mathrm{ng}$ total RNA. Adaptors containing unique molecular markers were ligated to the RNA before conversion into cDNA, PCR amplification and sequencing using a NextSeq500 instrument with an average number of reads of 75 million reads/sample. Raw data were de-multiplexed and FASTQ files generated using bcl2fastq software (Illumina Inc., San Diego, CA, USA). Reads were mapped and annotated using Bowtie2 v 2.2.2 (46) with GRCh37 as the reference genome and the miRbase 20 as annotation reference. Normalized counts were obtained using edgeR (47). The microRNA profiling results were analysed and visualised using the software Qlucore Omics Explorer version 3.6 (Qlucore, Lund, Sweden). Dimensionality reduction by principal component analysis (PCA) was used to identify expression patterns. Thresholds for the identification of differentially expressed microRNAs were absolute fold change $>2.0$ and false-discovery rate $<0.05$.

Target identification and Gene Ontology $(G O)$ analysis. The list of microRNAs found to be up-regulated and down-regulated in EBs were loaded into the open source software platform Cytoscape (version 3.8.2, cytoscape.org) (48) with the ClueGO app (v2.5.7) (49) installed to identify biological processes associated with the targets of the microRNAs found to be up- and down-regulated at day 30 vs. day 0 .

Panel screening of serum microRNAs by reverse transcriptasequantitative polymerase chain reaction ( $R T-q P C R)$. RNA from the serum samples of seven patients with teratoma in the primary tumour and nine patients in whom teratoma was found in lymph nodes at pcRPLND in addition to 10 healthy controls (Table II) were submitted to RT-qPCR screening using a custom-made panel consisting of 39 microRNAs (See Table III) with hsa-miR-30b-5p and hsa-miR-191-5p as endogenous controls. RNA, $2 \mu$, was transcribed to cDNA in $10-\mu l$ reactions using a miRCURY LNA RT Kit (Qiagen). qPCR was performed with 45 cycles using a 
A

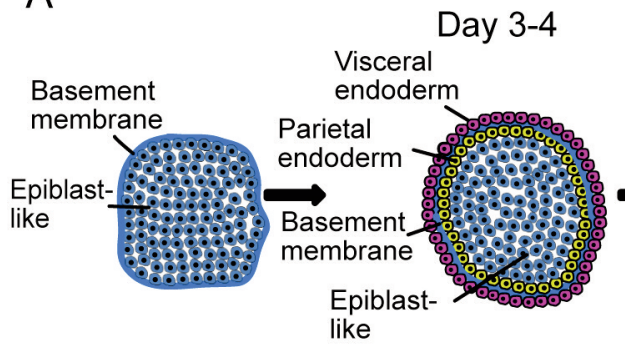

Day $>4$

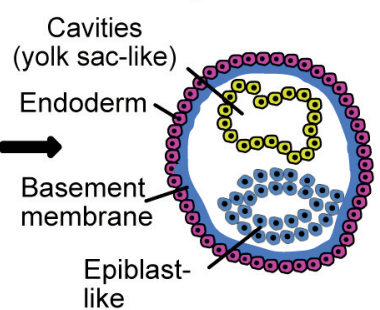

like
B

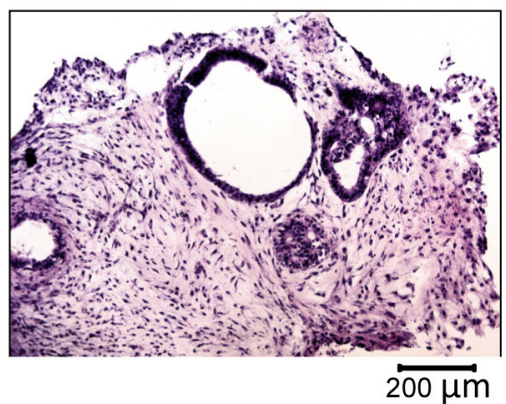

C

Day 2

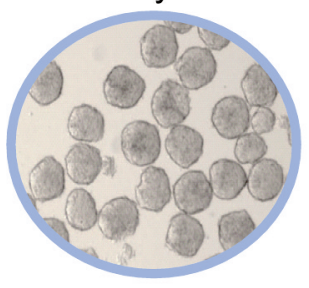

Day 8

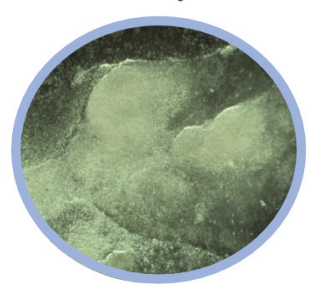

Day 20

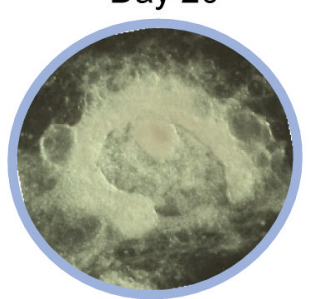

Day 30

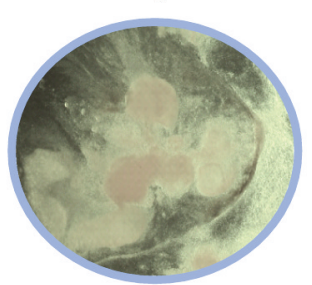

Figure 1. Structural development of embryoid bodies (EBs) from human induced pluripotent stem cells. A: Schematic showing the growth of cells from simple spherical aggregates to cystic EBs with one or more cavities. B: Cryosectioned and hematoxylin and eosin-stained EBs with cavities. $C$ : Images of EB morphology at the timepoints of sampling for microRNA analysis, showing simple spheres at day 2 , aggregated spheres at day 8 and tissue-like structures at days 20 and 30.

LightCycler 480 Real-Time PCR System (Roche, Basel, Switzerland) in 384-well plates. Haemolysis was assessed using the hsa-miR-23a-3p/hsa-miR-451a ratio (50).

RT-qPCR with pre-amp using TaqMan hydrolysis probes. MicroRNAs with positive amplification signal for serum from at least one patient with teratoma and no signal in the samples from the healthy donors in the panel screen were verified in a larger cohort consisting of seven patients with $>50 \%$ teratoma in the primary tumour, nine with viable teratoma in one or more lymph nodes at pcRPLND and 30 healthy males. cDNA was synthesised using a TaqMan MicroRNA Transcription Kit (Thermo Fisher Scientific) as recommended by the manufacturer. qPCR with preamplification was performed with a pool of the 20X TaqMan microRNA Assays TaqMan assays (See Supplementary Table I for assay list and protocol). Relative quantification was performed using miR-30b-5p as endogenous control, $\Delta \mathrm{Cq}=\mathrm{Cq}_{\text {target microRNA }}-\mathrm{Cq}_{\text {miR- }}$ $30 \mathrm{~b}-5 \mathrm{p}$. The relative quantities are given as $2-\Delta \mathrm{Cq}$.

Ethics statement. The patient samples analysed were included through the SWENOETCA-MIR study which was approved by the Regional Ethics Committee (REC Central Norway 2015/1475) and Regional Ethics Committee (REC Stockholm 2018/1730-31). Written, informed consent was obtained from all patients at inclusion, in accordance with the Declaration of Helsinki. We reprogrammed fibroblast cells from two donors from the Norwegian MODY Registry after written informed consent and with experiments approved by the Regional Committee of Medical Ethics (REK 2010/2295).
Statistical analysis. Expression levels in two groups were compared using the Mann-Whitney non-parametric $t$-test. All $p$-values were twotailed and considered statistically significant when $p<0.05$. Statistical analyses and plots were generated using Graph Pad Prism 9 (Graph Pad Software LLC, La Jolla, CA, USA) and figures were prepared using Affinity Designer (Serif Software Ltd, Nottingham, UK).

\section{Results}

MicroRNA expression in EBs. To identify potential novel teratoma biomarkers, we studied the microRNA profile at several timepoints during differentiation of hESCs and hiPSCs into EBs. Firstly, we developed EBs during a 30-day protocol and assessed a time-course microRNA expression profile to both validate the model and to allow subsequent correlative studies with microRNA gene expression in teratoma tissue and sera from patients with teratoma. We used two hiPSC lines from two healthy donors (N26 and N904), and the H1 hESC line to generate EBs. The EBs were grown as described from single cells into three-dimensional tissue-resembling cultures (Figure 1) containing ectodermal, mesodermal and endodermal germ components. We harvested cells for microRNA expression analysis on days 0 , 8,20 and 30. After microRNA sequencing, very lowabundant microRNAs were filtered out leaving 872 microRNAs in the dataset. We used differential expression 
analysis comparing days 8,20 and 30 to baseline day 0 to characterise the microRNA expression in the EBs at these cell harvest time points.

PCA identified a strong clustering by time points (Figure 2A) across different cell sources (H1 hESCs, hiPSCs) supporting our assumption of a predictable pace of differentiation regardless of the cell source and hence justifying our grouping of time point data at the selected time points. The PCA plot showed differences in the expression levels of microRNAs between H1 hESCs and hiPSCs at the early timepoints, but the global expression profiles converged towards the late timepoints (Figure 2A). We identified the most down-regulated (Figure 2B) and the most up-regulated (Figure 2C) microRNAs in the samples from day 30 compared to day 0 and day 8 . As expected, expression of miRNA pluripotency markers, the miR-302/367 and miR-520 clusters, faded with differentiation from day 0 to day 30 in all three EB cultures (Supplementary Figure 1). The miR-371-373 cluster was stably expressed in all three EB cultures at all timepoints. miR-375-3p was weakly expressed at day 0 but the expression increased and remained relatively high from day 8 for the hiPSC EB cultures (N26 and N904), and from day 20 for the H1 hESC EB culture.

The microRNAs with increased expression at days 20 and 30 included miR-10b, miR-10a, miR-143, miR-145, miR-23a, miR-23b, miR-125b and miR-100, which have previously been shown to be highly expressed in differentiated hiPSCs $(51,52)$, validating our model. Consistent with the development of more differentiated tissue during EB development, we identified the GO terms "epithelial cell proliferation and development", "tube formation" and "mesenchymal cell differentiation" for the top down-regulated microRNAs (Supplementary Figure 2 and Supplementary Table II). The GO terms "cell differentiation", "circulatory system development", "tube morphogenesis", "odontogenesis", "embryonic morphogenesis", and "urogenital system development" and "brain development" were identified for the top up-regulated microRNAs (Supplementary Figure 3 and Supplementary Table III). Furthermore, GO terms and pathways detected include regulation of the apoptotic signalling pathway, regulation of the extracellular signal-regulated protein kinase 1 (ERK1) and ERK2 cascade, regulation of the mitogen-activated protein kinase 3 (MAPK3), erythroblastic leukemia viral oncogene (ERBB) signalling pathway, among others in the top down-regulated microRNAs and regulation of WNT-signaling pathway, immune system development, cellular response to oxidative stress, among others in the top upregulated microRNA.

microRNA expression in teratoma tissue. RNA was extracted from FFPE tissue from 19 tissue specimens from seven patients diagnosed with teratoma. Of these, five specimens were from primary teratomas in the testes of five of the patients (Figure 3), six specimens were from teratomas in lymph node metastases of three of the patients, one specimen was from a primary teratoma in the mediastinum and one specimen was from teratoma in the lung in the same patient (See Table I for more information). The study also included RNA from normal testicular tissue from four of the patients in addition to two specimens from normal lymph nodes.

Differential expression analysis of normal testicular tissue compared to teratoma tissue showed that the normal tissue was clearly separated from teratoma tissue based on the PCA analysis of microRNA expression (Figure 4A). The microRNAs most up-regulated in teratoma versus normal testicular tissue are shown in Figure 4B (fold change $>3$, false-discovery rate $<0.05)$. Figure $4 \mathrm{C}$ shows the microRNAs down-regulated in teratoma versus normal tissue. We next compared these disease-specific miRNAs with the miRNA expression in the EB model by overlap analysis (Figure 5), in particular the miRNAs appearing in the latest phase (day 30) of EB differentiation. Of the microRNAs up-regulated in the teratomas, 19 were also up-regulated in the EBs at day 30, among them miR-193a-3p, miR-196a-5p, miR-196b-3p, miR-223-5p and miR-490-3p and miR-490-5p. Eleven microRNAs were down-regulated in both the teratomas and the EBs (Figure 5A, Supplementary Table IV). Among these were miR-520c-3p and miR-520-3p, which are members of the primate-specific microRNA gene cluster (C19MC). Members of the miR-17-92 cluster, miR-19a-3p, miR-19-15p, miR-20a-5p and miR-92a-1-5p, were also down-regulated in both the differentiated EBs and teratoma FFPE. miR-454$5 \mathrm{p}$ and miR-363-3p were up-regulated in the teratomas, but down-regulated in the EBs at day 30. The miR-371-373 cluster, showing stable expression in the EBs (Supplementary Figure 1) and the miR-302/367 cluster, showing decreasing expression with time in the EBs, were expressed in testicular teratoma tissue and to some degree in normal testicular tissue, but not in the teratomas from the lymph node metastases (Figure 5B and Figure 6). The previously proposed teratoma marker, miR-375-3p, was expressed at higher levels in primary teratoma from the testes and teratoma metastases in lymph nodes, mediastinum and lungs than in normal tissue from testis and in normal lymph nodes (Figure 6A). The expression was, however, not statistically significant different, with overlapping confidence intervals for testicular teratoma tissue, normal testicular tissue and teratoma from lymph node metastases (Figure 6B).

microRNA screening in serum. MicroRNAs found to be upregulated in teratoma tissue and in the differentiated EBs (Figure 5C and D) were filtered against serum microRNA profiles from healthy individuals to remove microRNAs known to be highly expressed in the serum compartment of healthy individuals. MicroRNAs reported to be up-regulated in teratoma datasets published by others were also included in the screening $(53,54)$ (See Supplementary Table V for full list of 
A

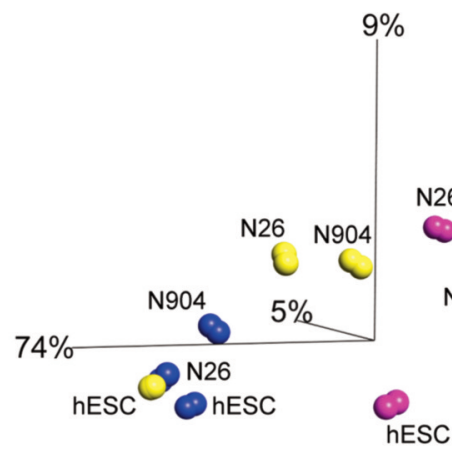

B

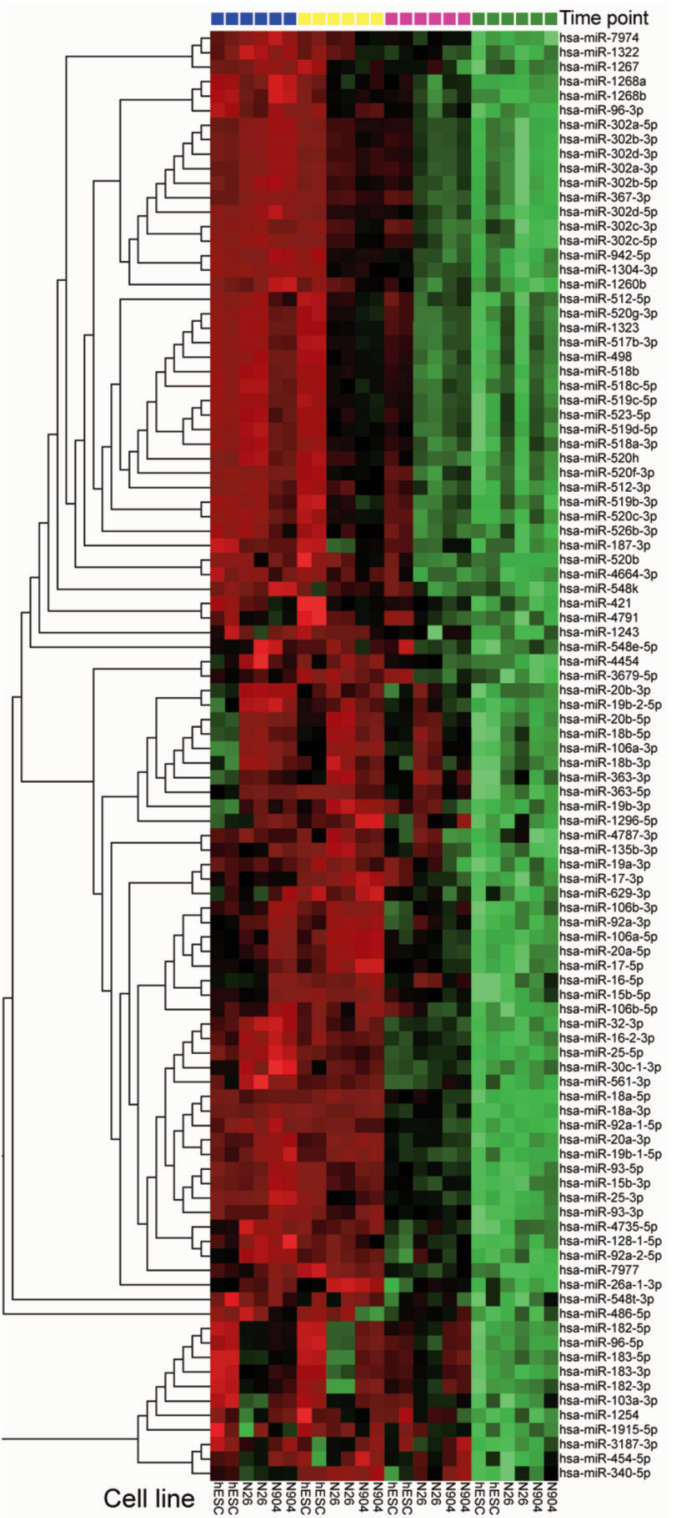

C

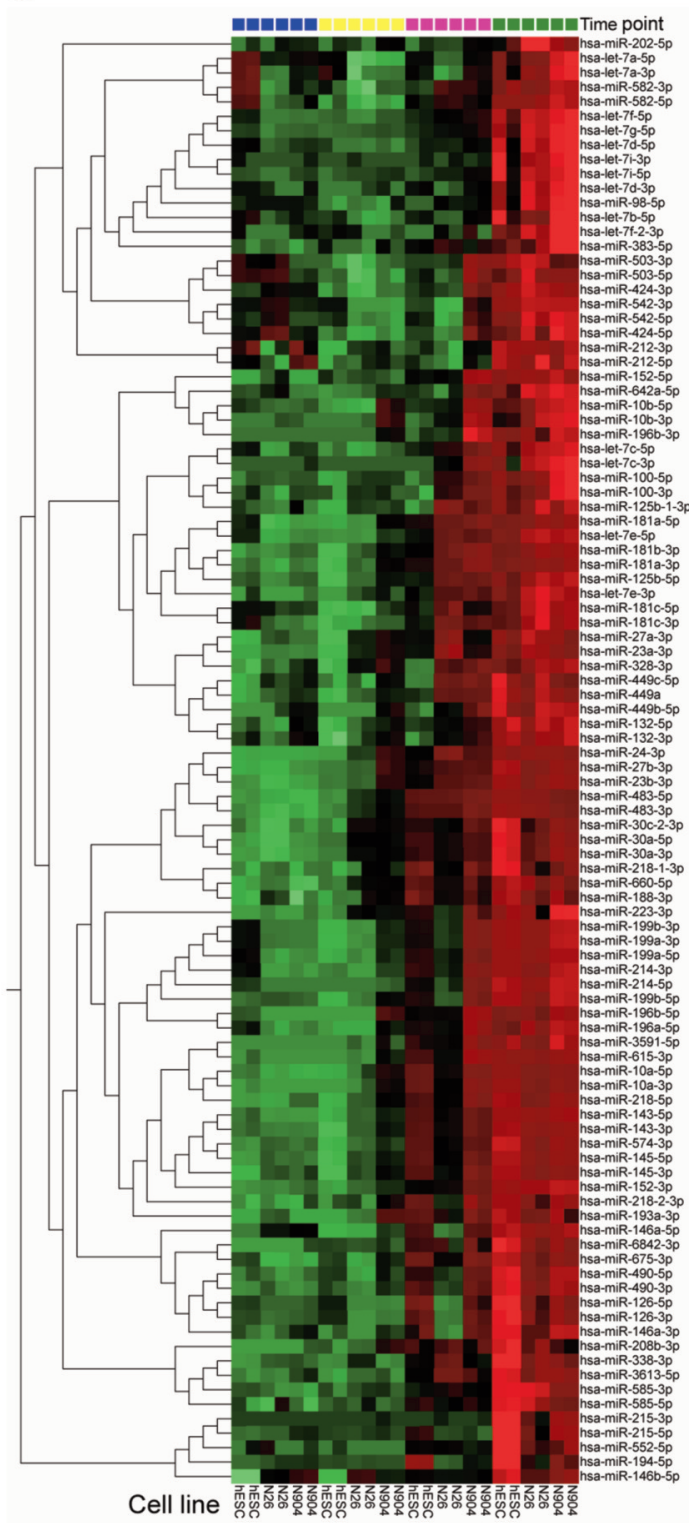

Figure 2. MicroRNA expression in the embryoid bodies (EBs) at different timepoints. A: Principal component analysis (PCA) plot based on similarities in microRNA expression showing the clustering of samples from the two human induced pluripotent stem cell cultures (N26 and N904) and the human embryonic stem cell culture (hESC) at days 0,8 and 20 versus day 30 (fold change $>3$, false-discovery rate <0.05). B and C: Heatmaps indicating the relative expression at days 0, 8, 20 and 30 for the most down-regulated and up-regulated microRNAs, respectively. 

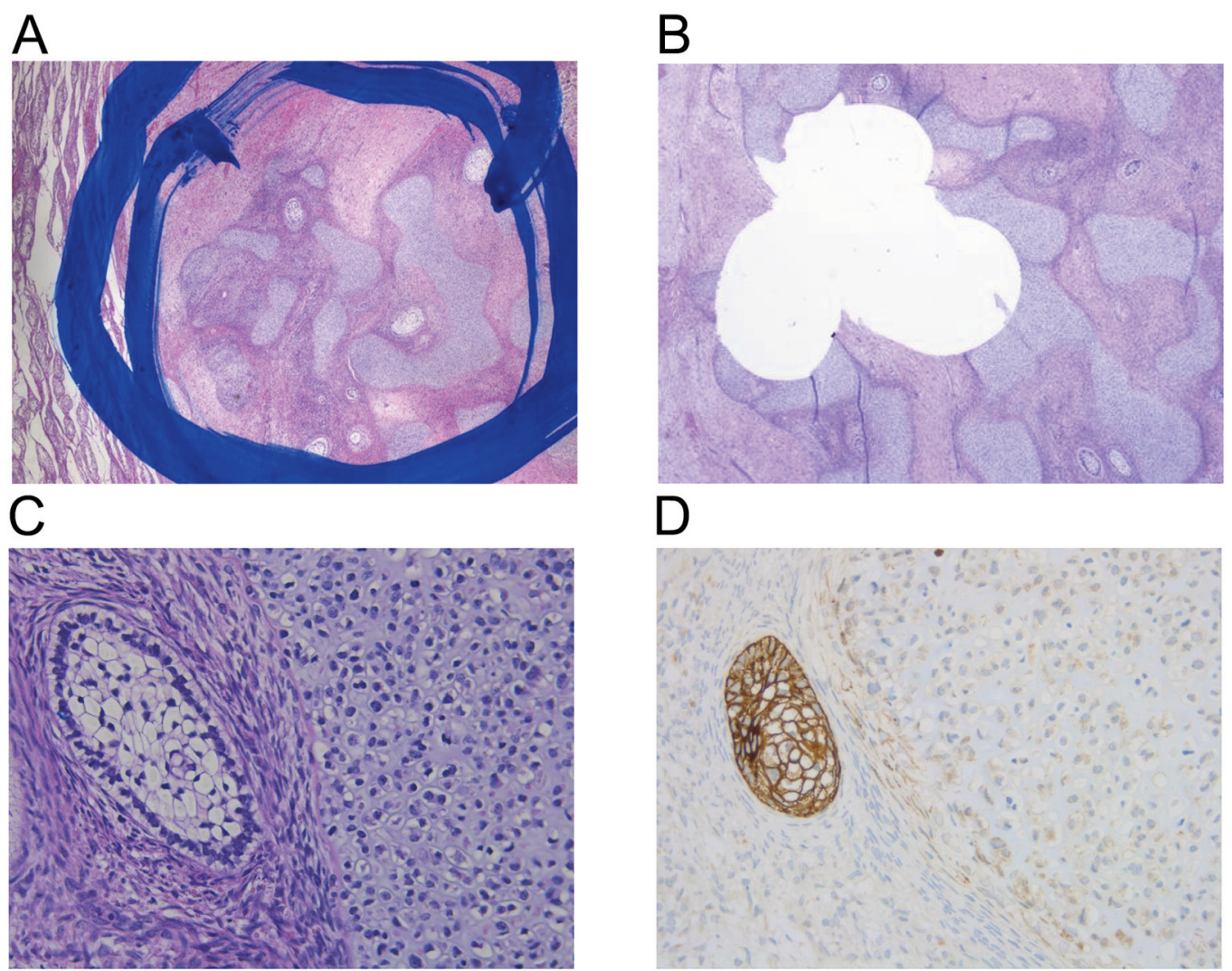

Figure 3. Extraction of tissue cores from formalin-fixed paraffin-embedded teratoma tissue. A: Encircled area of teratoma before extraction [hematoxylin and eosin (HE)]. B: Area of teratoma after extraction of three tissue cores (HE). C: Epithelial (left) and chondroidal (right) components of teratoma. D: Immunohistochemical staining showed positivity for cytokeratin (CKAE1/AE3) in the epithelial component.

microRNAs). The microRNAs were measured in serum samples from healthy controls and patients using a custom RTqPCR panel for microRNA screening. The serum screen included samples from ten healthy males and 16 teratoma patients of whom seven cases had primary tumour with $>50 \%$ teratoma cells and nine cases had teratoma in lymph nodes from pcRPLND (see Table II for patient characteristics). The results from the screening showed that most of the microRNAs in our candidate panel were either highly expressed in serum from both healthy individuals and patients or not detected at all in any of them (Supplementary Table VI), hence these miRNAs were omitted from further analysis. However, miR222-5p, miR-200a-5p, miR-454-5p and miR-196b-3p were not expressed in any of the sera from healthy donors but were weakly expressed in at least one of the teratoma patient samples and kept for further analysis. These four microRNAs were further analysed by RT-qPCR with pre-amplification in an extended set of 16 patients (Table II) and 30 healthy blood donors as controls. miR-222-5p (Figure 7A) was expressed at equal levels in sera from the patients with teratoma and the healthy controls $(p=0.39)$, and hence is not a potential circulating biomarker. miR-200a-5p (Figure 7B) and miR196b-3p (Figure 7C) were both expressed at low levels in serum after the pre-amplification procedure but were not statistically differentially expressed when comparing patients with teratoma and healthy controls in the extended cohort ( $p=0.76$ and $p=0.11$, respectively). miR-454-5p (Figure 7D), which was up-regulated in teratoma tissue but down-regulated in the EBs at day 30, was also found to be expressed at the same low magnitude in serum from both controls and patients $(p=0.53)$. miR-371a-3p (Figure 7E) was weakly expressed in the serum from one patient with primary tumour described as pure teratoma, in two patients where teratoma was mixed with $\mathrm{EC}$, and in three patients with teratoma mixed with yolk sac tumour. None of the patients with teratoma in lymph nodes at the time of pcRPLND expressed miR-371a-3p. For miR-375$3 p$ (Figure 7F) the mean serum expression level was statistically significant higher in patients compared to controls $(p=0.012)$. The expression was high in serum from both patients and controls, with overlap of the $95 \%$ confidence intervals between controls (95\% confidence interval $=0.05-0.13$ ) and teratoma cases ( $95 \%$ confidence interval $=0.11-0.36$ ). 
A
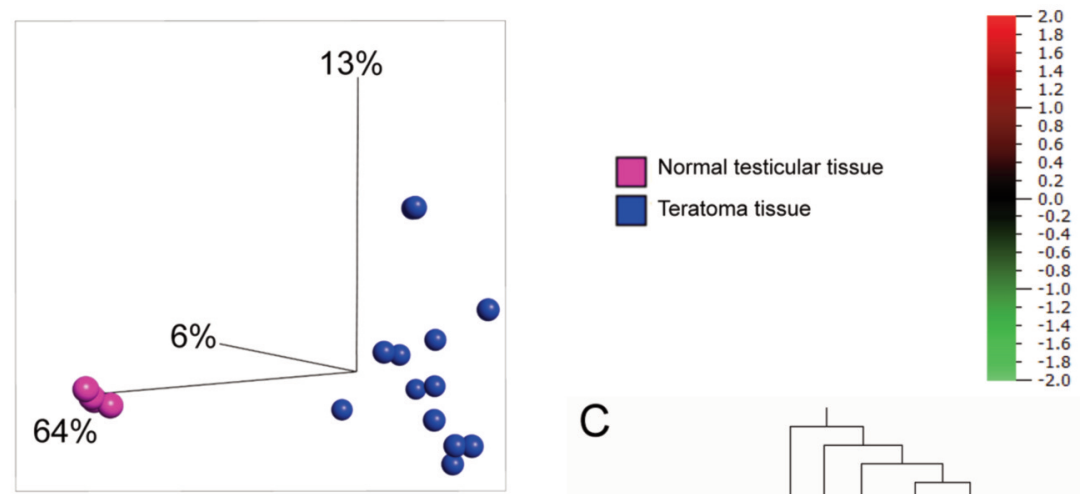

B
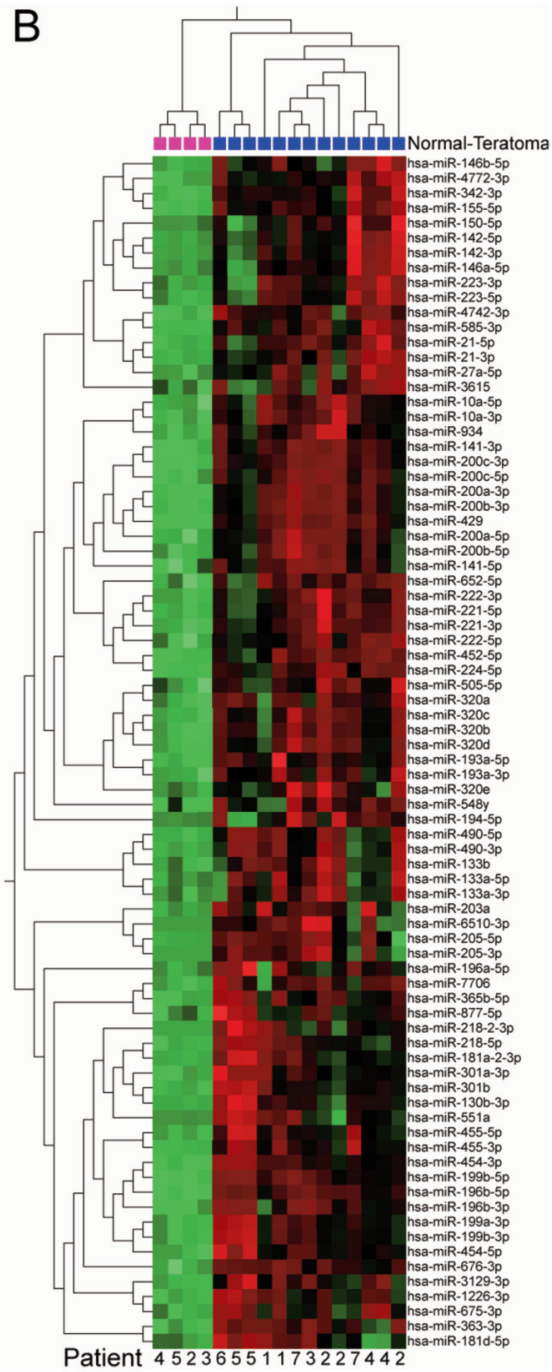

C
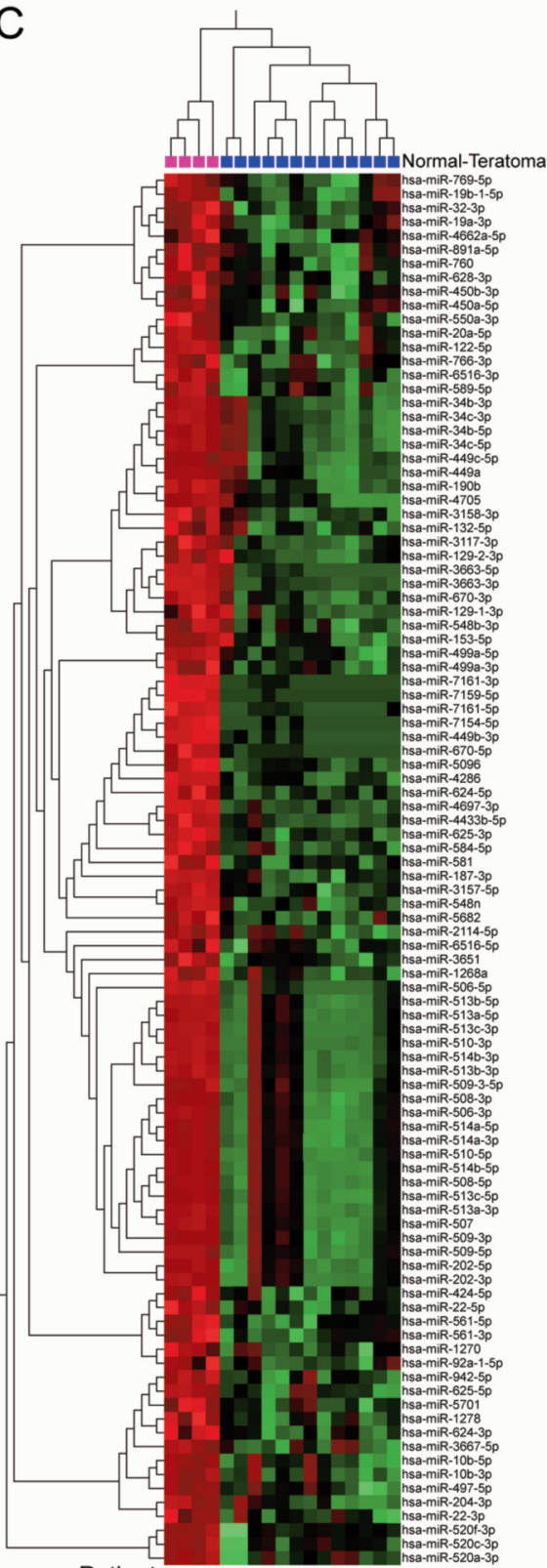

Patient 45231122327744655

Figure 4. MicroRNA expression in formalin-fixed paraffin-embedded samples of testicular teratoma and normal testicular tissue. A: Principal component analysis plot showing the clustering of normal testicular tissue versus teratoma tissue based on the microRNA expression (fold change $>3$, false-discovery rate $<0.05)$. Heatmaps showing the microRNAs most up-regulated $(B)$ and down-regulated $(C)$ in teratoma tissue versus normal testicular tissue. Several patients are represented with multiple samples, as indicated at the bottom of the heatmaps. 
A

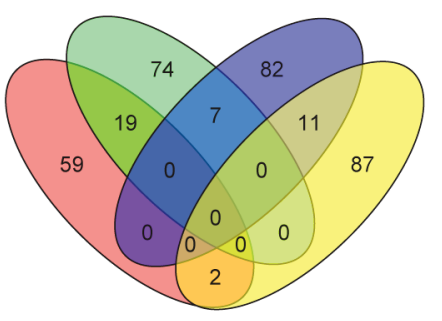

Teratoma, up-regulated

Embryoid bodies, up-regulated day 30

Teratoma, down-regulated

Embryoid bodies, down-regulated day 30
B

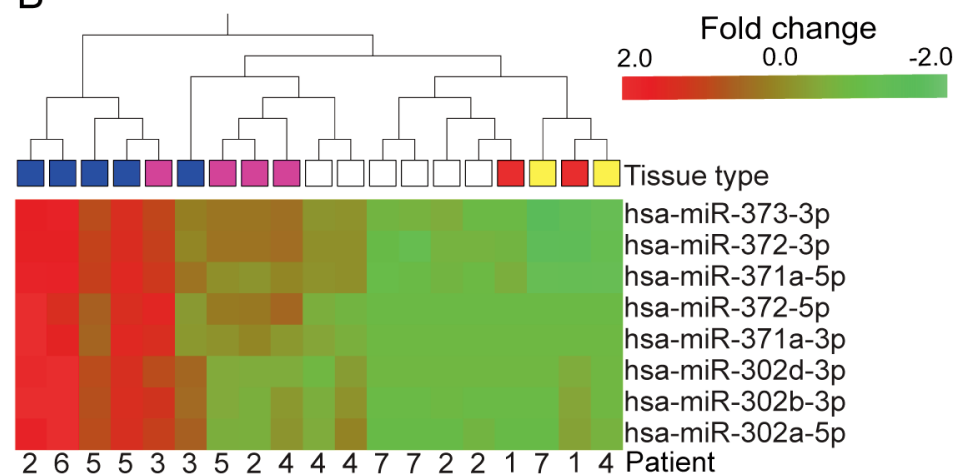

Tissue type

Normal lymph node Normal testis

Teratoma lymph node Teratoma testis

Teratoma mediastinum and lung
C

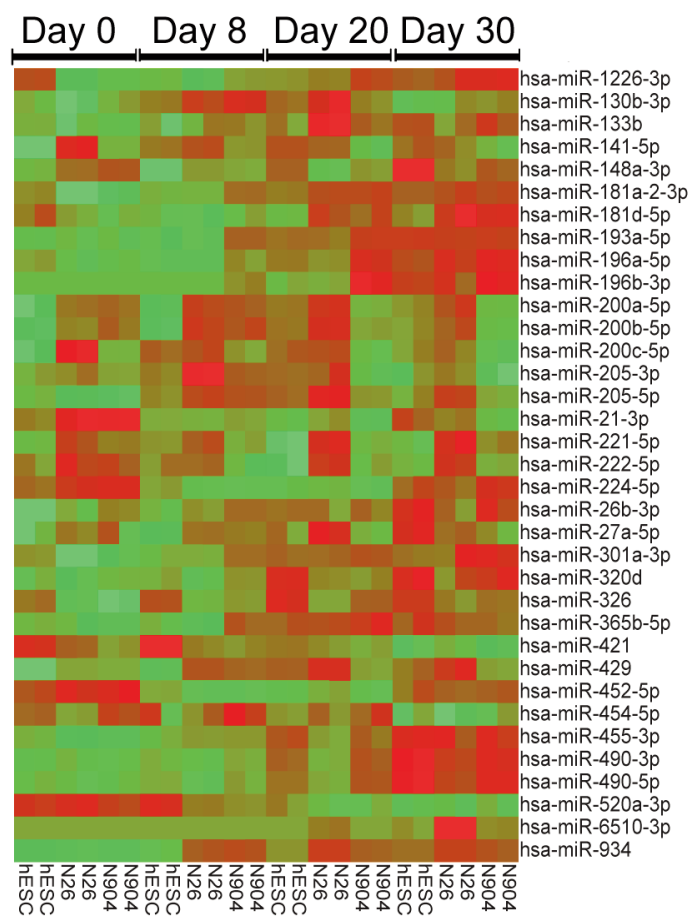

D

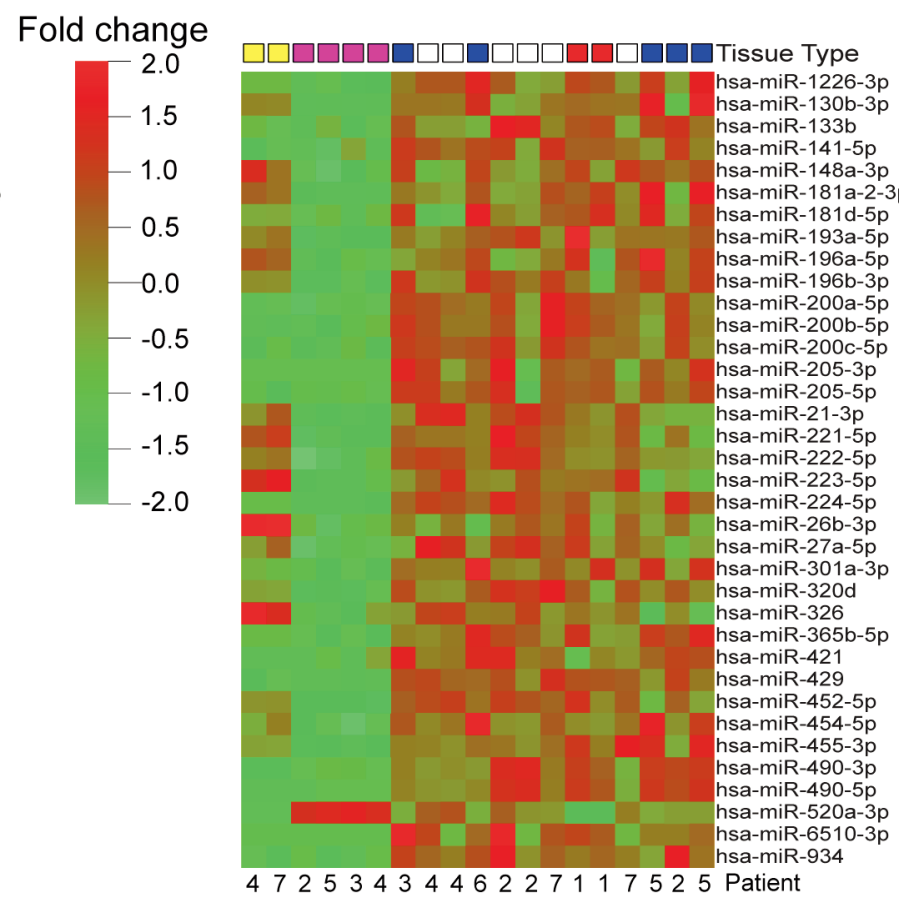

Figure 5. MicroRNA expression in teratoma tissue compared to embryoid bodies. A: Venn diagram showing the overlap between the microRNAs up-regulated and down-regulated in teratoma tissue and embryoid bodies. B: Expression of microRNAs in the miR-302/367 and miR-371-373 clusters in tissue from teratoma and normal corresponding normal tissue. C: Expression of the microRNAs identified as the best biomarker candidates for teratoma in the embryoid body cultures at different timepoints. D: Expression of the microRNA biomarker candidates in teratoma tissue and corresponding normal tissue.

\section{Discussion}

In the present study, we searched for microRNAs as potential novel biomarkers for the teratoma subtype of TGCT. We employed hES- and hiPSC-derived EBs to model the cellular differentiation that occurs from precursor cells to mature teratomas in TGCT. Investigating overlap with tissue and serum microRNA expression identified miR-222-5p, miR200a-5p, miR196b-3p and miR-454-5p as potential novel candidate circulating biomarkers of the teratoma subtype of 
A

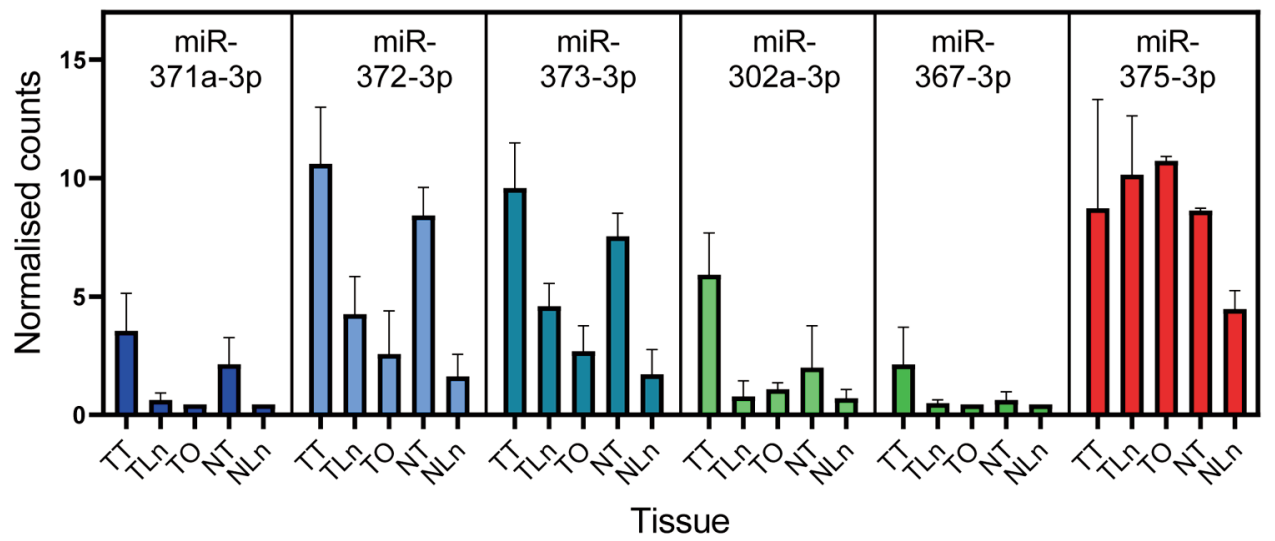

B

\begin{tabular}{|l|c|}
\hline Tissue & miR-375-3p \\
\hline Teratoma, testes $\mathrm{N}=5$ & $8.7(3.0-14.4)$ \\
\hline Teratoma, lymph node $(\mathrm{N}=6)$ & $10.2(7.6-12.8)$ \\
\hline Teratoma, other sites $(\mathrm{N}=2)$ & $10.7(9.1-12.4)$ \\
\hline Normal testicular tissue $(\mathrm{N}=4)$ & $8.6(8.5-8.8)$ \\
\hline Normal lymph node $(\mathrm{N}=2)$ & $4.5(-2.5-11.5)$ \\
\hline
\end{tabular}

Figure 6. A: Expression of miR-375-3p and selected microRNAs of the miR-302/367 and miR-371-373 clusters in formalin-fixed paraffin-embedded teratoma tissue from testicular tumours (TT, N=5), lymph node metastases (TLn, $N=6)$, other metastases (TO, lung N=1, mediastinum $N=1)$, normal testicular tissue $(N T, N=4)$ and normal tissue from lymph nodes $(N L n, N=2)$. Data are the mean expression with standard deviation. B: The mean normalised counts with $95 \%$ confidence intervals for miR-375-3p are stated in the table.

TGCT but validation studies did not confirm a clinically useful role. However, the hiPSC-derived EB model system seemed robust and aligned well with previous miRNA findings, warranting further exploration of this model.

Microscopically, a testicular tissue specimen containing teratoma may appear histologically benign and contain highly differentiated mature, or embryonic immature, tissue from one or more of the three germ layers (mesoderm, ectoderm, endoderm), e.g., cartilage, teeth, and hair. However, these teratomas have the ability to grow invasively and metastasise. The scientific challenge is, in a circulating biomarker test, to identify the changes that occur in teratomas that account for their malignant features. To model this process, we used the ability of human pluripotent stem cells to form differentiated EBs (37-39). We grew EBs from H1 hESCs and hiPSCs and harvested samples from the cultures at baseline, and then after 8,20 and 30 days in order to study patterns in microRNA expression as these cells differentiated and developed into tissue bodies containing ectoderm, mesoderm and endoderm, resembling postpubertal teratomas. Our analysis showed a differential expression of microRNAs between EBs from H1 hESCs and hiPSCs at the early timepoints but, in concordance with previously published reports, the microRNA expression pattern of $\mathrm{H} 1 \mathrm{hESC}$ and hiPSCs became more similar with increasing time in culture (52). Most of the changes in microRNA expression between day 0 and day 30 EBs can be ascribed to cellular and tissue differentiation processes. The microRNAs down-regulated at day 30 were associated with positive regulation of the cell cycle, DNA damage checkpoint, and regulation of programmed cell death, while those up-regulated were associated with tissue development, cell differentiation, regulation of metabolic processes and senescence. These findings suggest that the most differentially expressed microRNAs at day 30 compared to day 0 were typical of the normal differentiation process of cells, but some of the changes may also represent invasive processes. Suh et al. discovered in 2004 that the miR302/367 and miR-371-373 clusters were specific for undifferentiated hESCs and the early embryonic stage (55). A later study designed to test whether microRNAs predicted risk of post transplantation tumour in therapeutic use of hiPSCs showed that miR-371-373 and miR-302/367 clusters were not expressed in xenografts of mice injected with hiPSCs that developed into pure teratomas (teratoma assay) (56). On the other hand, xenografts that contained elements with a minor yolk sac component in addition to the teratoma did express miR-371a-3p. Our findings are in line with these 

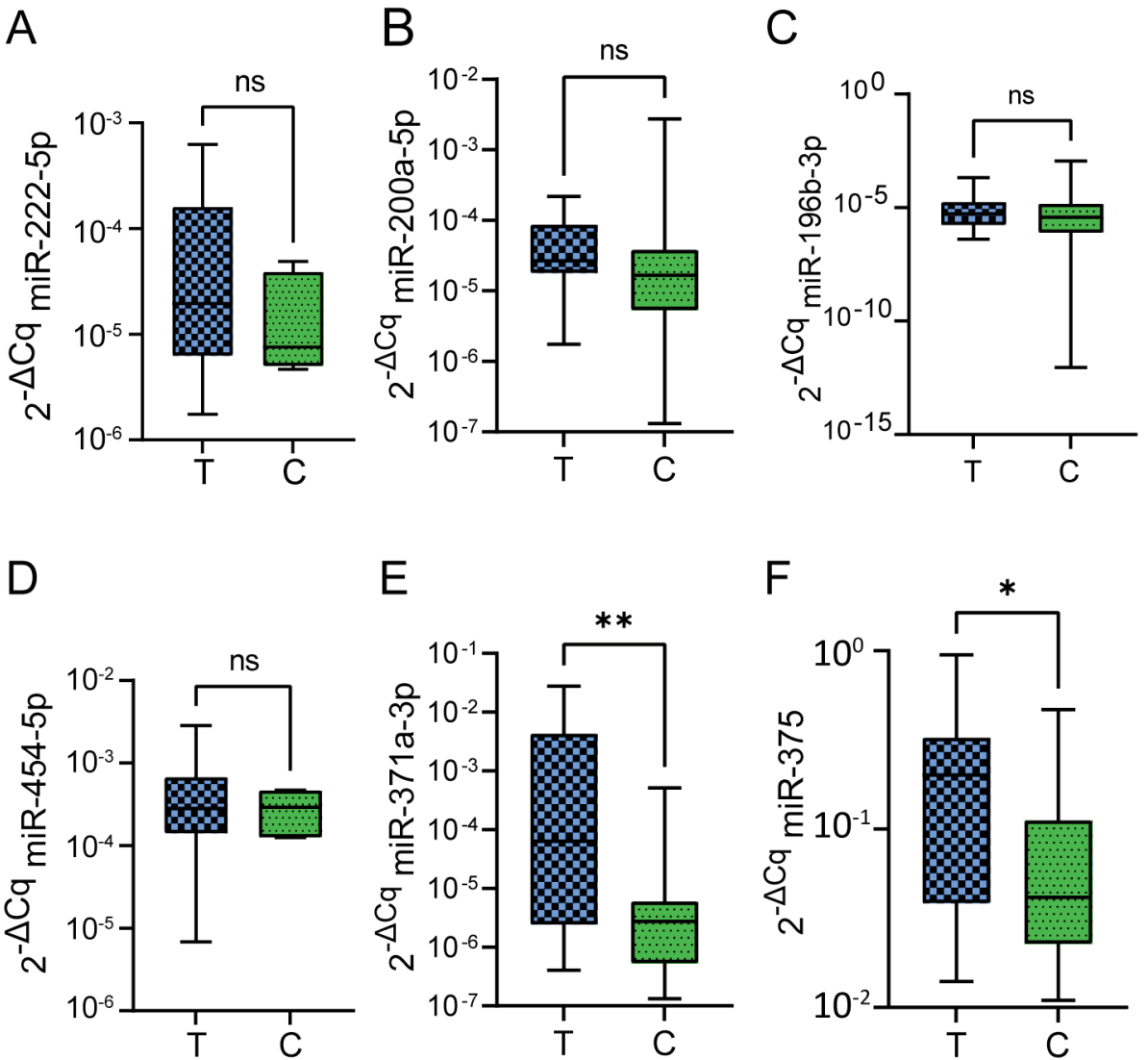

Figure 7. Expression of miR-222-5p (A), miR-200a-5p (B), miR-196b-3p (C), miR-454-5p (D), miR-371a-3p (E) and miR-375-3p (F) in serum from patients with teratoma $(T)(N=16)$ and healthy, male controls $(C)(N=30)$. Mean relative quantities with $95 \%$ confidence intervals are shown. *Significantly different at $p<0,05$; ns: not significantly different.

findings. Our results show that expression of the miR$302 / 367$ cluster is high in undifferentiated cells and diminishes with differentiation, as expected from previous published reports $(55,57,58)$. The miR371-373 cluster was expressed at low levels, with no clear decrease or increase of expression during the time course of the EB culture. Members of the primate-specific C19MC, which is located in the vicinity of miR371-373 on chromosome 19, was found to be down-regulated during differentiation of hiPSC into EBs in another study (59). The C19MC has been studied in TGCT and found to represent promising circulating biomarkers in non-seminomas $(60,61)$. Our results from teratoma tissue indicates that this cluster was lowly expressed in teratomas, which is consistent with the results reported by Flor et al. (61).

From our microRNA expression studies in EBs and FFPE tissue from teratomas, we identified a list of miRNAs expressed at high levels in differentiated EBs and teratomas which we further investigated as putative circulating candidate biomarkers. Most of these microRNAs were either undetectable or not different between patients and controls in the RT-qPCR screen of serum samples. We further studied miR-222-5p, miR-454-5p, miR-196b-3p and miR-200a-5p that were identified to be expressed in serum from patients with teratoma but not in healthy controls. To this end, we used an extended cohort analysed by RT-qPCR including a preamplification step, which increases the sensitivity of the detection method. The results showed no statically significant difference in expression between patients with teratoma and healthy controls. These five microRNAs were generally weakly expressed and detected in few patients even with the pre-amplification step included in the RT-qPCR method. miR371a-3p, which has been previously reported as a circulating biomarker $(31,42,62-68)$ was found to be weakly expressed in serum from one patient with primary TGCT described as pure teratoma, but was not expressed in any of the serum samples collected prior to pcRPLND from patients with pure teratoma in the post-chemotherapy RPLND specimen. In tissue, our finding of a gradient in expression of miR-371a-3p from tumour, through normal testicular tissue to non-testicular 
tissue is in concordance with the report from Belge et al. (69). miR-375-3p has been shown in a molecular characterisation of TGCT to be expressed in teratomas (10) and was later proposed as a marker for teratomas in conjunction with miR$371 \mathrm{a}-3 \mathrm{p}(32,67)$. We found that the expression of miR-375$3 p$ increased after day 8 of the EB cultures. In tissue, we did not find statistically significantly differences in miR-375-3p expression levels in teratoma tissue from tumours localized to the testes, compared to lymph nodes or lungs/mediastinum and normal testicular tissue. Normal lymphoid tissue had lower levels of miR-375-3p than normal testicular tissue. Our sample size was too small to draw any conclusions regarding miR$375-3 p$ expression in tissue but the results from tissue together with our finding from the EBs showing that miR-375-3p expression increased during differentiation, indicates that miR$375-3 p$ is expressed not only in teratoma and testicular tissue, but also in differentiated, normal somatic tissues. In serum, we found the mean expression of $\mathrm{miR}-375-3 \mathrm{p}$ to be higher in patients with teratoma compared to healthy controls, but the 95\% confidence intervals overlapped, reducing the discriminatory potential. We conclude that miR-375-3p is not a good serum marker for teratoma in our studies, consistent with other recently published studies $(10,34-36)$.

To conclude, we identified miR-222-5p, miR-200a-5p, miR-196b-3p and miR-454-5p as candidate biomarkers for teratoma, but further analysis in serum contradicted the discriminatory value of these microRNAs. The fact that the teratomas are often highly differentiated and have traits of normal, somatic tissues makes the search for a circulating biomarker challenging because the plasma compartment of the blood harbours a cross section of molecules shed from cells and tissues throughout the body. A microRNA not normally present in testicular tissue but highly expressed in teratomas may also be found at high levels in other normal and highly differentiated tissue and will thus not be detected above the background signal in a serum or plasma sample, as shown here for miR-375-3p.

\section{Supplementary Material}

Supplementary Figures and Tables are available at: https:// 1 drv.ms/u/s!AnUCtk5rLUTliqF7KEg9aSDMn30H9w?e=eVXevS or upon request to the corresponding author.

\section{Conflicts of Interest}

The Authors declare no potential conflicts of interest exist.

\section{Authors' Contributions}

MPM: Conceptualization, methodology, data curation, funding acquisition, software, formal analysis and writing of the article. AMS: Methodology, laboratory analyses and preparation of the article. OJH: Histological and pathological assessment and preparation of the article. AT: Resources and preparation of the article. OD: Conceptualization, investigation, funding acquisition and preparation of the article. HR: Conceptualization, methodology, funding acquisition and writing of the article.

\section{Acknowledgements}

The Authors thank Bendik Nordanger and Benedikte Rosenlund for excellent technical support. We also thank the Mohn Cancer Research Laboratory for providing excellent general laboratory facilities. This study was funded by Trond Mohn Foundation to H.R, The Western Norway Regional Health Authority Research funding, Grant 911-980 to O.D. Grant from the Fund for Cancer Research, Department of Oncology and Medical Physics to M.P.M. Research funds at CLINTEC, Karolinska Institutet to A.T.

\section{References}

1 Bray F, Ferlay J, Soerjomataram I, Siegel RL, Torre LA and Jemal A: Global cancer statistics 2018: GLOBOCAN estimates of incidence and mortality worldwide for 36 cancers in 185 countries. CA Cancer J Clin 68(6): 394-424, 2018. PMID: 30207593. DOI: $10.3322 /$ caac. 21492

2 Znaor A, Lortet-Tieulent J, Jemal A and Bray F: International variations and trends in testicular cancer incidence and mortality. Eur Urol 65(6): 1095-1106, 2014. PMID: 24268506. DOI: 10.1016/j.eururo.2013.11.004

3 Bromen K, Stang A, Baumgardt-Elms C, Stegmaier C, Ahrens W, Metz KA and Jöckel KH: Testicular, other genital, and breast cancers in first-degree relatives of testicular cancer patients and controls. Cancer Epidemiol Biomarkers Prev 13(8): 1316-1324, 2004. PMID: 15298952.

4 McGlynn KA and Trabert B: Adolescent and adult risk factors for testicular cancer. Nat Rev Urol 9(6): 339-349, 2012. PMID: 22508459. DOI: $10.1038 /$ nrurol.2012.61

5 Litchfield K, Levy M, Huddart RA, Shipley J and Turnbull C: The genomic landscape of testicular germ cell tumours: from susceptibility to treatment. Nat Rev Urol 13(7): 409-419, 2016. PMID: 27296647. DOI: 10.1038/nrurol.2016.107

6 Wang Z, McGlynn KA, Rajpert-De Meyts E, Bishop DT, Chung CC, Dalgaard MD, Greene MH, Gupta R, Grotmol T, Haugen TB, Karlsson R, Litchfield K, Mitra N, Nielsen K, Pyle LC, Schwartz SM, Thorsson V, Vardhanabhuti S, Wiklund F, Turnbull C, Chanock SJ, Kanetsky PA, Nathanson KL and Testicular Cancer Consortium: Meta-analysis of five genomewide association studies identifies multiple new loci associated with testicular germ cell tumor. Nat Genet 49(7): 1141-1147, 2017. PMID: 28604732. DOI: $10.1038 / n g .3879$

7 Lafin JT, Bagrodia A, Woldu S and Amatruda JF: New insights into germ cell tumor genomics. Andrology 7(4): 507-515, 2019. PMID: 30896089. DOI: 10.1111/andr.12616

8 Litchfield K, Loveday C, Levy M, Dudakia D, Rapley E, Nsengimana J, Bishop DT, Reid A, Huddart R, Broderick P, Houlston RS and Turnbull C: Large-scale sequencing of testicular germ cell tumour (TGCT) cases excludes major TGCT predisposition gene. Eur Urol 73(6): 828-831, 2018. PMID: 29433971. DOI: 10.1016/j.eururo.2018.01.021

9 Loveday C, Law P, Litchfield K, Levy M, Holroyd A, Broderick P, Kote-Jarai Z, Dunning AM, Muir K, Peto J, Eeles R, Easton DF, Dudakia D, Orr N, Pashayan N, UK Testicular Cancer 
Collaboration, The PRACTICAL Consortium., Reid A, Huddart RA, Houlston RS and Turnbull C: Large-scale analysis demonstrates familial testicular cancer to have polygenic aetiology. Eur Urol 74(3): 248-252, 2018. PMID: 29935977 DOI: $10.1016 /$ j.eururo.2018.05.036

10 Shen H, Shih J, Hollern DP, Wang L, Bowlby R, Tickoo SK, Thorsson V, Mungall AJ, Newton Y, Hegde AM, Armenia J, Sánchez-Vega F, Pluta J, Pyle LC, Mehra R, Reuter VE, Godoy G, Jones J, Shelley CS, Feldman DR, Vidal DO, Lessel D, Kulis T, Cárcano FM, Leraas KM, Lichtenberg TM, Brooks D, Cherniack AD, Cho J, Heiman DI, Kasaian K, Liu M, Noble MS, Xi L, Zhang H, Zhou W, ZenKlusen JC, Hutter CM, Felau I, Zhang J, Schultz N, Getz G, Meyerson M, Stuart JM, Cancer Genome Atlas Research Network, Akbani R, Wheeler DA, Laird PW, Nathanson KL, Cortessis VK and Hoadley KA: Integrated molecular characterization of testicular germ cell tumors. Cell Rep 23(11): 3392-3406, 2018. PMID: 29898407. DOI: 10.1016/j.celrep.2018.05.039

11 Rijlaarsdam MA and Looijenga LH: An oncofetal and developmental perspective on testicular germ cell cancer. Semin Cancer Biol 29: 59-74, 2014. PMID: 25066859. DOI: 10.1016/j.semcancer.2014.07.003

12 McGlynn KA and Cook MB: Etiologic factors in testicular germ-cell tumors. Future Oncol 5(9): 1389-1402, 2009. PMID: 19903067. DOI: $10.2217 /$ fon.09.116

13 Jørgensen N, Müller J, Giwercman A, Visfeldt J, Møller H and Skakkebaek NE: DNA content and expression of tumour markers in germ cells adjacent to germ cell tumours in childhood: probably a different origin for infantile and adolescent germ cell tumours. J Pathol 176(3): 269-278, 1995. PMID: 7674089. DOI: 10.1002/path.1711760309

14 Berney DM, Looijenga LH, Idrees M, Oosterhuis JW, RajpertDe Meyts E, Ulbright TM and Skakkebaek NE: Germ cell neoplasia in situ (GCNIS): evolution of the current nomenclature for testicular pre-invasive germ cell malignancy. Histopathology 69(1): 7-10, 2016. PMID: 26918959. DOI: 10.1111/his.12958

15 Williamson SR, Delahunt B, Magi-Galluzzi C, Algaba F, Egevad L, Ulbright TM, Tickoo SK, Srigley JR, Epstein JI, Berney DM and Members of the ISUP Testicular Tumour Panel: The World Health Organization 2016 classification of testicular germ cell tumours: a review and update from the International Society of Urological Pathology Testis Consultation Panel. Histopathology 70(3): 335-346, 2017. PMID: 27747907. DOI: 10.1111/his.13102

16 Moch H, Cubilla AL, Humphrey PA, Reuter VE and Ulbright TM: The 2016 WHO classification of tumours of the urinary system and male genital organs-part A: Renal, penile, and testicular tumours. Eur Urol 70(1): 93-105, 2016. PMID: 26935559. DOI: $10.1016 /$ j.eururo.2016.02.029

17 Visfeldt J, Jørgensen N, Müller J, Møller H and Skakkebaek NE: Testicular germ cell tumours of childhood in Denmark, 19431989: incidence and evaluation of histology using immunohistochemical techniques. J Pathol 174(1): 39-47, 1994. PMID: 7965402. DOI: 10.1002/path.1711740107

18 Leibovitch I, Foster RS, Ulbright TM and Donohue JP: Adult primary pure teratoma of the testis. The Indiana experience. Cancer 75(9): 2244-2250, 1995. PMID: 7712432. DOI: 10.1002/10970142(19950501)75:9<2244::aid-cncr2820750909>3.0.co;2-i

19 Simmonds PD, Lee AH, Theaker JM, Tung K, Smart CJ and Mead GM: Primary pure teratoma of the testis. J Urol 155(3): 939-942, 1996. PMID: 8583612.
20 Bustamante-Marín X, Garness JA and Capel B: Testicular teratomas: an intersection of pluripotency, differentiation and cancer biology. Int J Dev Biol 57(2-4): 201-210, 2013. PMID: 23784831. DOI: $10.1387 /$ ijdb.130136bc

21 Funt SA, Patil S, Feldman DR, Motzer RJ, Bajorin DF, Sheinfeld J, Tickoo SK, Reuter VE and Bosl GJ: Impact of teratoma on the cumulative incidence of disease-related death in patients with advanced germ cell tumors. J Clin Oncol 37(26): 2329-2337, 2019. PMID: 31233353. DOI: 10.1200/JCO.18.01608

22 Brydøy M, Oldenburg J, Klepp O, Bremnes RM, Wist EA, Wentzel-Larsen T, Hauge ER, Dahl $O$ and Fosså SD: Observational study of prevalence of long-term Raynaud-like phenomena and neurological side effects in testicular cancer survivors. J Natl Cancer Inst 101(24): 1682-1695, 2009. PMID: 19940282. DOI: $10.1093 /$ jnci/djp413

23 Mayer F, Wermann H, Albers P, Stoop H, Gillis AJ, Hartmann JT, Bokemeyer CC, Oosterhuis JW, Looijenga LH and Honecker F: Histopathological and molecular features of late relapses in non-seminomas. BJU Int 107(6): 936-943, 2011. PMID: 20955261. DOI: 10.1111/j.1464-410X.2010.09631.x

24 Umbreit EC, Siddiqui BA, Hwang MJ, Joon AY, Maity T, Westerman ME, Merriman KW, Alhasson H, Uthup J, Guo T, Moore JA, Ward JF, Karam JA, Wood CG, Pisters LL, Zhang M and Tu SM: Origin of subsequent malignant neoplasms in patients with history of testicular germ cell tumor. Cancers (Basel) 12(12): 3755, 2020. PMID: 33327406. DOI: 10.3390/cancers12123755

25 Chadalavada RS, Korkola JE, Houldsworth J, Olshen AB, Bosl GJ, Studer L and Chaganti RS: Constitutive gene expression predisposes morphogen-mediated cell fate responses of NT2/D1 and 27X-1 human embryonal carcinoma cells. Stem Cells 25(3): 771-778, 2007. PMID: 17138961. DOI: 10.1634/stemcells.20060271

26 Mueller T, Mueller LP, Luetzkendorf J, Voigt W, Simon H and Schmoll HJ: Loss of Oct-3/4 expression in embryonal carcinoma cells is associated with induction of cisplatin resistance. Tumour Biol 27(2): 71-83, 2006. PMID: 16557044. DOI: 10.1159/000 092324

27 Taylor-Weiner A, Zack T, O’Donnell E, Guerriero JL, Bernard B, Reddy A, Han GC, AlDubayan S, Amin-Mansour A, Schumacher SE, Litchfield K, Turnbull C, Gabriel S, Beroukhim R, Getz G, Carter SL, Hirsch MS, Letai A, Sweeney C and Van Allen EM: Genomic evolution and chemoresistance in germ-cell tumours. Nature 540(7631): 114-118, 2016. PMID: 27905446. DOI: $10.1038 /$ nature 20596

28 Korkola JE, Houldsworth J, Bosl GJ and Chaganti RS: Molecular events in germ cell tumours: linking chromosome-12 gain, acquisition of pluripotency and response to cisplatin. BJU Int 104(9 Pt B): 1334-1338, 2009. PMID: 19840009. DOI: 10.1111/j.1464-410X.2009.08855.x

29 Einhorn LH and Foster RS: What are the indications for postchemotherapy retroperitoneal lymph node dissection? Ann Oncol 25(2): 301-303, 2014. PMID: 24389117. DOI: 10.1093/ annonc/mdt493

30 De Giorgi U, Pupi A, Fiorentini G, Rosti G and Marangolo M: FDG-PET in the management of germ cell tumor. Ann Oncol 16(Suppl 4): iv90-iv94, 2005. PMID: 15923438. DOI: 10.1093/ annonc/mdi915

31 Dieckmann KP, Radtke A, Geczi L, Matthies C, Anheuser P, Eckardt U, Sommer J, Zengerling F, Trenti E, Pichler R, Belz H, Zastrow S, Winter A, Melchior S, Hammel J, Kranz J, Bolten M, 
Krege S, Haben B, Loidl W, Ruf CG, Heinzelbecker J, Heidenreich A, Cremers JF, Oing C, Hermanns T, Fankhauser CD, Gillessen S, Reichegger H, Cathomas R, Pichler M, Hentrich M, Eredics K, Lorch A, Wülfing C, Peine S, Wosniok W, Bokemeyer $\mathrm{C}$ and Belge G: Serum levels of microRNA-371a-3p (M371 Test) as a new biomarker of testicular germ cell tumors: Results of a prospective multicentric study. J Clin Oncol 37(16): 1412-1423, 2019. PMID: 30875280. DOI: 10.1200/JCO.18.01480

32 Nappi L, Thi M, Adra N, Hamilton RJ, Leao R, Lavoie JM, Soleimani M, Eigl BJ, Chi K, Gleave M, So A, Black PC, Bell R, Daneshmand S, Cary C, Masterson T, Einhorn L, Nichols C and Kollmannsberger $\mathrm{C}$ : Integrated expression of circulating miR375 and miR371 to identify teratoma and active germ cell malignancy components in malignant germ cell tumors. Eur Urol 79(1): 16-19, 2021. PMID: 33158661. DOI: 10.1016/j.eururo. 2020.10 .024

33 Kremer L, von Brandenstein M, Wittersheim M, Koeditz B, Paffenholz P, Hellmich M, Pfister D, Heidenreich A and Nestler T: The combination of microRNA-371a-3p and 375-5p can distinguish viable germ cell tumor and teratoma from necrosis in postchemotherapy retroperitoneal lymph node dissection specimens. Transl Androl Urol 10(4): 1647-1655, 2021. PMID: 33968653. DOI: $10.21037 /$ tau-20-1349

34 Lafin JT, Kenigsberg AP, Meng X, Abe D, Savelyeva A, Singla N, Woldu SL, Lotan Y, Mauck RJ, Lewis CM, Margulis V, Wong D, Jia L, Kapur P, Xu L, Speir RW, Chesnut GT, Frazier AL, Strand DW, Coleman N, Murray MJ, Amatruda JF and Bagrodia A: Serum small RNA sequencing and miR-375 assay do not identify the presence of pure teratoma at postchemotherapy retroperitoneal lymph node dissection. Eur Urol Open Sci 26: 83-87, 2021. PMID: 33997822. DOI: 10.1016/j.euros.2021.02.003

35 Belge G, Grobelny F, Matthies C, Radtke A and Dieckmann KP: Serum level of microRNA-375-3p is not a reliable biomarker of teratoma. In Vivo 34(1): 163-168, 2020. PMID: 31882475. DOI: 10.21873/invivo. 11757

36 Lobo J, Gillis AJM, van den Berg A, Dorssers LCJ, Belge G, Dieckmann KP, Roest HP, van der Laan LJW, Gietema J, Hamilton RJ, Jerónimo C, Henrique R, Salvatori D and Looijenga LHJ: Identification and validation model for informative liquid biopsy-based microRNA biomarkers: Insights from germ cell tumor in vitro, in vivo and patient-derived data. Cells 8(12): 1637, 2019. PMID: 31847394. DOI: 10.3390/cells8121637

37 Ungrin MD, Joshi C, Nica A, Bauwens C and Zandstra PW: Reproducible, ultra high-throughput formation of multicellular organization from single cell suspension-derived human embryonic stem cell aggregates. PLoS One 3(2): e1565, 2008 PMID: 18270562. DOI: 10.1371/journal.pone.0001565

38 Chen KG, Mallon BS, Johnson KR, Hamilton RS, McKay RD and Robey PG: Developmental insights from early mammalian embryos and core signaling pathways that influence human pluripotent cell growth and differentiation. Stem Cell Res 12(3): 610-621, 2014. PMID: 24603366. DOI: 10.1016/j.scr.2014.02.002

39 Kleinsmith LJ and Pierce GB Jr: Multipotentiality of single embryonal carcinoma cells. Cancer Res 24: 1544-1551, 1964. PMID: 14234000.

40 International Stem Cell Initiative: Assessment of established techniques to determine developmental and malignant potential of human pluripotent stem cells. Nat Commun 9(1): 1925, 2018. PMID: 29765017. DOI: 10.1038/s41467-018-04011-3
41 Bjørlykke Y, Søviknes AM, Hoareau L, Vethe H, Mathisen AF, Chera S, Vaudel M, Ghila LM and Ræder H: Reprogrammed cells display distinct proteomic signatures associated with colony morphology variability. Stem Cells Int 2019: 8036035, 2019. PMID: 31827534. DOI: 10.1155/2019/8036035

42 Myklebust MP, Thor A, Rosenlund B, Gjengst $\varnothing$ P, Karlsdottir Á, Brydøy M, Bercea BS, Olsen C, Johnson I, Berg MI, Langberg CW, Andreassen KE, Kjellman A, Haugnes HS and Dahl O: Serum miR371 in testicular germ cell cancer before and after orchiectomy, assessed by digital-droplet PCR in a prospective study. Sci Rep 11(1): 15582, 2021. PMID: 34341387. DOI: 10.1038/s41598-021-94812-2

43 Tonge DP and Gant TW: What is normal? Next generation sequencing-driven analysis of the human circulating miRNAOme. BMC Mol Biol 17: 4, 2016. PMID: 26860190. DOI: $10.1186 / \mathrm{s} 12867-016-0057-9$

44 Danielson KM, Rubio R, Abderazzaq F, Das S and Wang YE: High throughput sequencing of extracellular RNA from human plasma. PLoS One 12(1): e0164644, 2017. PMID: 28060806. DOI: 10.1371 /journal.pone.0164644

45 Myklebust MP, Rosenlund B, Gjengst $\varnothing$ P, Bercea BS, Karlsdottir Á, Brydøy M and Dahl O: Quantitative PCR measurement of miR-371a-3p and miR-372-p is influenced by hemolysis. Front Genet 10: 463, 2019. PMID: 31191602. DOI: 10.3389/fgene. 2019.00463

46 Langmead B and Salzberg SL: Fast gapped-read alignment with Bowtie 2. Nat Methods 9(4): 357-359, 2012. PMID: 22388286. DOI: $10.1038 /$ nmeth.1923

47 Robinson MD, McCarthy DJ and Smyth GK: edgeR: a Bioconductor package for differential expression analysis of digital gene expression data. Bioinformatics 26(1): 139-140, 2010. PMID: 19910308. DOI: 10.1093/bioinformatics/btp616

48 Shannon P, Markiel A, Ozier O, Baliga NS, Wang JT, Ramage D, Amin N, Schwikowski B and Ideker T: Cytoscape: a software environment for integrated models of biomolecular interaction networks. Genome Res 13(11): 2498-2504, 2003. PMID: 14597658. DOI: $10.1101 /$ gr.1239303

49 Bindea G, Mlecnik B, Hackl H, Charoentong P, Tosolini M, Kirilovsky A, Fridman WH, Pagès F, Trajanoski Z and Galon J: ClueGO: a Cytoscape plug-in to decipher functionally grouped gene ontology and pathway annotation networks. Bioinformatics 25(8): 1091-1093, 2009. PMID: 19237447. DOI: 10.1093/ bioinformatics/btp101

50 Blondal T, Jensby Nielsen S, Baker A, Andreasen D, Mouritzen P, Wrang Teilum $M$ and Dahlsveen IK: Assessing sample and miRNA profile quality in serum and plasma or other biofluids. Methods 59(1): S1-S6, 2013. PMID: 23036329. DOI: 10.1016/j.ymeth.2012.09.015

51 Wilson KD, Venkatasubrahmanyam S, Jia F, Sun N, Butte AJ and Wu JC: MicroRNA profiling of human-induced pluripotent stem cells. Stem Cells Dev 18(5): 749-758, 2009. PMID: 19284351. DOI: $10.1089 / \mathrm{scd} .2008 .0247$

52 Chin MH, Mason MJ, Xie W, Volinia S, Singer M, Peterson C, Ambartsumyan G, Aimiuwu O, Richter L, Zhang J, Khvorostov I, Ott V, Grunstein M, Lavon N, Benvenisty N, Croce CM, Clark AT, Baxter T, Pyle AD, Teitell MA, Pelegrini M, Plath K and Lowry WE: Induced pluripotent stem cells and embryonic stem cells are distinguished by gene expression signatures. Cell Stem Cell 5(1): 111-123, 2009. PMID: 19570518. DOI: 10.1016/ j.stem.2009.06.008 
53 Gillis AJ, Stoop HJ, Hersmus R, Oosterhuis JW, Sun Y, Chen C, Guenther S, Sherlock J, Veltman I, Baeten J, van der Spek PJ, de Alarcon P and Looijenga LH: High-throughput microRNAome analysis in human germ cell tumours. J Pathol 213(3): 319-328, 2007. PMID: 17893849 . DOI: $10.1002 /$ path.2230

54 Ding Y, Gu XY, Xu F, Shi XY, Yang DZ, Zhong J and Wang SM: MicroRNA expression profiling of mature ovarian teratomas. Oncol Lett 3(1): 35-38, 2012. PMID: 22740852. DOI: $10.3892 / \mathrm{ol} .2011 .438$

55 Suh MR, Lee Y, Kim JY, Kim SK, Moon SH, Lee JY, Cha KY, Chung HM, Yoon HS, Moon SY, Kim VN and Kim KS: Human embryonic stem cells express a unique set of microRNAs. Dev Biol 270(2): 488-498, 2004. PMID: 15183728. DOI: 10.1016/ j.ydbio.2004.02.019

56 Salvatori DCF, Dorssers LCJ, Gillis AJM, Perretta G, van Agthoven T, Gomes Fernandes M, Stoop H, Prins JB, Oosterhuis JW, Mummery C and Looijenga LHJ: The MicroRNA-371 family as plasma biomarkers for monitoring undifferentiated and potentially malignant human pluripotent stem cells in teratoma assays. Stem Cell Reports 11(6): 1493-1505, 2018. PMID: 30503260. DOI: 10.1016/j.stemcr.2018.11.002

57 Bar M, Wyman SK, Fritz BR, Qi J, Garg KS, Parkin RK, Kroh EM, Bendoraite A, Mitchell PS, Nelson AM, Ruzzo WL, Ware C, Radich JP, Gentleman R, Ruohola-Baker H and Tewari M: MicroRNA discovery and profiling in human embryonic stem cells by deep sequencing of small RNA libraries. Stem Cells 26(10): 2496-2505, 2008. PMID: 18583537. DOI: 10.1634/ stemcells.2008-0356

58 Ren J, Jin P, Wang E, Marincola FM and Stroncek DF: MicroRNA and gene expression patterns in the differentiation of human embryonic stem cells. J Transl Med 7: 20, 2009. PMID: 19309508. DOI: 10.1186/1479-5876-7-20

59 Razak SR, Ueno K, Takayama N, Nariai N, Nagasaki M, Saito R, Koso H, Lai CY, Murakami M, Tsuji K, Michiue T, Nakauchi $\mathrm{H}$, Otsu $\mathrm{M}$ and Watanabe S: Profiling of microRNA in human and mouse ES and iPS cells reveals overlapping but distinct microRNA expression patterns. PLoS One 8(9): e73532, 2013. PMID: 24086284. DOI: 10.1371/journal.pone.0073532

60 Murray MJ, Smith S, Ward D, Verduci L, Nicholson JC, Scarpini $\mathrm{CG}$ and Coleman N: Circulating microRNAs as biomarkers to assist the management of the malignant germ-cell-tumour subtype choriocarcinoma. Transl Oncol 14(1): 100904, 2021. PMID: 33049521. DOI: 10.1016/j.tranon.2020.100904

61 Flor I, Spiekermann M, Löning T, Dieckmann KP, Belge G and Bullerdiek J: Expression of microRNAs of C19MC in different histological types of testicular germ cell tumour. Cancer Genomics Proteomics 13(4): 281-289, 2016. PMID: 27365378.

62 Voorhoeve PM, le Sage C, Schrier M, Gillis AJ, Stoop H, Nagel R, Liu YP, van Duijse J, Drost J, Griekspoor A, Zlotorynski E, Yabuta N, De Vita G, Nojima H, Looijenga LH and Agami R: A genetic screen implicates miRNA-372 and miRNA-373 as oncogenes in testicular germ cell tumors. Cell 124(6): 11691181, 2006. PMID: 16564011. DOI: 10.1016/j.cell.2006.02.037
63 Gillis AJ, Rijlaarsdam MA, Eini R, Dorssers LC, Biermann K, Murray MJ, Nicholson JC, Coleman N, Dieckmann KP, Belge G, Bullerdiek J, Xu T, Bernard N and Looijenga LH: Targeted serum miRNA (TSmiR) test for diagnosis and follow-up of (testicular) germ cell cancer patients: a proof of principle. Mol Oncol 7(6): 1083-1092, 2013. PMID: 24012110. DOI: 10.1016/j.molonc. 2013.08.002

64 Belge G, Dieckmann KP, Spiekermann M, Balks T and Bullerdiek $\mathrm{J}$ : Serum levels of microRNAs miR-371-3: a novel class of serum biomarkers for testicular germ cell tumors? Eur Urol 61(5): 10681069, 2012. PMID: 22386195. DOI: 10.1016/j.eururo.2012.02.037

65 Syring I, Bartels J, Holdenrieder S, Kristiansen G, Müller SC and Ellinger J: Circulating serum miRNA (miR-367-3p, miR371a-3p, miR-372-3p and miR-373-3p) as biomarkers in patients with testicular germ cell cancer. J Urol 193(1): 331-337, 2015. PMID: 25046619. DOI: 10.1016/j.juro.2014.07.010

66 Murray MJ, Halsall DJ, Hook CE, Williams DM, Nicholson JC and Coleman N: Identification of microRNAs from the miR371 373 and miR-302 clusters as potential serum biomarkers of malignant germ cell tumors. Am J Clin Pathol 135(1): 119-125, 2011. PMID: 21173133. DOI: 10.1309/AJCPOE11KEYZCJHT

67 Nappi L, Thi M, Lum A, Huntsman D, Eigl BJ, Martin C, O'Neil B, Maughan BL, Chi K, So A, Black PC, Gleave M, Wyatt AW, Lavoie JM, Khalaf D, Bell R, Daneshmand S, Hamilton RJ, Leao RRN, Nichols C and Kollmannsberger C: Developing a highly specific biomarker for germ cell malignancies: Plasma miR371 expression across the germ cell malignancy spectrum. J Clin Oncol 37(33): 3090-3098, 2019. PMID: 31553692 . DOI: $10.1200 / \mathrm{JCO} .18 .02057$

68 Leão R, van Agthoven T, Figueiredo A, Jewett MAS, Fadaak K, Sweet J, Ahmad AE, Anson-Cartwright L, Chung P, Hansen A, Warde P, Castelo-Branco P, O'Malley M, Bedard PL, Looijenga LHJ and Hamilton RJ: Serum miRNA predicts viable disease after chemotherapy in patients with testicular nonseminoma germ cell tumor. J Urol 200(1): 126-135, 2018. PMID: 29474847. DOI: 10.1016/j.juro.2018.02.068

69 Belge G, Hennig F, Dumlupinar C, Grobelny F, Junker K, Radtke A and Dieckmann KP: Graded expression of microRNA-371a-3p in tumor tissues, contralateral testes, and in serum of patients with testicular germ cell tumor. Oncotarget 11(16): 1462-1473, 2020. PMID: 32363003. DOI: 10.18632/oncotarget.27565
Received November 1, 2021

Revised January 14, 2022

Accepted January 20, 2022 